\title{
Market Response to European Regulation of Business Combinations
}

\author{
by
}

\author{
Nihat Aktas, Eric de Bodt, and Richard Roll
}

September 5, 2001

\begin{abstract}
Acquisitions, mergers and other business agreements are facing increasing regulatory scrutiny, even when they are among firms domiciled outside the territory of the regulatory authorities. Some noteworthy recent examples involve mergers between American firms that were prohibited by regulators from the European Commission. Reciprocation by regulators from other jurisdictions seems a likely future trend. There are obvious consequences for the successful completion of proposed global business arrangements. With extra-territorial intervention, the chance of prohibition by at least one group of regulators is, of course, much larger than by any single jurisdiction. This paper explains the regulatory procedures of the European Commission with respect to business combinations. It documents the price reactions of subject firms on various dates from the initial announcement to the final regulatory decision. There is evidence that the market can predict the outcome of a regulatory investigation. Despite allegations in the American financial press, there is little evidence that European regulators discriminate against non-European firms by either investigating them more assiduously or prohibiting their combinations more often.
\end{abstract}

\begin{tabular}{|r|l|l|l|}
\cline { 2 - 4 } \multicolumn{1}{c|}{ Aktas } & \multicolumn{1}{c|}{ DeBodt } & \multicolumn{1}{c|}{ Roll } \\
\hline \multirow{5}{*}{ address } & Université Catholique de Louvain & Université de Lille 2-Esa & The Anderson School \\
& 1 place des Doyens & 1 place Déliot - BP381 & UCLA \\
& 1348 Louvain-la-Neuve & 59020 Lille Cédex & Los Angeles, CA 90095-1481 \\
& BELGIUM & FRANCE & USA \\
\hline voice & $32-10-478-447$ & $33-3-2090-7477$ & $1-310-825-6118$ \\
\hline fax & $32-10-478-324$ & $33-3-2090-7702$ & $1-310-206-8404$ \\
\hline e-mail & aktas@fin.ucl.ac.be & edebodt@hp-sc.univ-lille2.fr & rroll@anderson.ucla.edu \\
\hline
\end{tabular}


The summer of 2001 witnessed an unprecedented event in the history of business combinations. Two American companies, General Electric and Honeywell, obtained approval to merge from all American regulatory agencies, but the merger was blocked by regulators in Europe. There have been few, if any, events that point so vividly to global market integration. Two decades ago, Europeans would have scarcely noticed mergers beyond their borders, yet they are now paying close attention and have erected a system of severe sanctions against non-European firms who might be tempted to defy their regulatory edicts. ${ }^{1}$

European challenges to the GE/Honeywell merger were followed closely in the American financial press and, because of its size and especially the outcome, it is probably the bestknown situation of its kind to date. It is, however, far from the first. ${ }^{2}$ Beginning in September 1990 through the end of December, 1999, the regulatory authorities of the European Commission received 1,228 notifications of proposed business combinations of all types ${ }^{3}$.

Because of data limitations to be described in detail below (mainly because the firms were not listed on a stock exchange), we are able to study only 602 proposed combinations. Approximately $17 \%$ of these were between entirely non-European firms. Another 32\% involved a European and a non-European firm and 51\% were entirely European. To our knowledge, European investigations have not been widely reciprocated by other countries, though there have been some instances. For example, American regulators recently blocked a merger between France's Air Liquide and Britain's BOC Group, even though it had been approved in Europe.

\footnotetext{
${ }^{1}$ Sanctions include fines and exclusion from European markets of products of offending companies.

${ }^{2}$ Two other widely publicized recent cases were the Boeing/McDonnell Douglas merger of 1997, which was finally approved after a number of concessions by the companies involved (see Aktas, et. al., 2000), and the proposed EMI/Time Warner deal of 2000, which was scuttled, (see Wall Street Journal, 2000.)

${ }^{3}$ Business combinations include mergers, acquisitions, joint ventures, and agreements to share assets. Through the end of July, 2001, the number of notifications had grown to 1,785. However, because of the delay in accessing both regulatory and market data, we were obliged to restrict our sample to notifications through the end of 1999.
} 
Such reciprocity seems likely to become more common because the impetus behind cross-border regulatory action is quite understandable. If local consumers will be harmed when products from abroad become more expensive owing to monopoly power acquired through merger, government might seem justified in attempting a remedy in advance. We do not assert that potential monopoly power actually did exist in any of the combinations challenged by the European Commission. Indeed, some have alleged that European regulators are more motivated by a desire to shelter local firms from foreign competition than by a yearning to protect consumers; [Cf. Priest and Romani (2001)]. Whatever the true motive, the pretext for regulatory challenge is politically persuasive and must therefore be tempting to regulators everywhere.

The adoption of similar regulations by several jurisdictions could become a serious barrier to global business combinations, unless regulators agree to harmonize their interventions. Imagine two merging firms doing business in, say, five regions. If regulatory theories and actions are roughly independent across regions, even a modest probability of blockage by any single regional regulator could translate into a very large probability of blockage by at least one. A study of interventions by European regulators, who have been the most active over the past decade, should be informative with respect to the long-term consequences of this growing regulatory trend.

Thus, our purpose in this paper is to provide a systematic account of the stock market's response to European regulatory activity. We have collected a virtually complete record of actions through 1999 pertaining to publicly traded companies, along with stock price and volume responses in the respective local markets around action announcement dates. One thing is clear: although the extent of European regulation was not widely appreciated by the U.S. public prior to the GE/Honeywell event, stock markets seemed to understand it very well. There are strong price reactions to European regulatory announcements. The specifics, to be described in detail in the paper, are fascinating.

The data reveal that mergers with greater promise of value creation attract closer scrutiny from EEC regulators, which is consistent with their stated anti-monopoly objective. Non- 
european firms are subjected to extensive scrutiny only slightly more often than European firms, which is not strong support for an objective of protecting European firms from foreign competition. Of course neither is absolute proof of, respectively, potential monopoly profits and an absence of anti-competitive protectionism.

We find that the market has some forecasting ability with respect to the final decision handed down by European regulators. For example, proposed mergers that are ultimately forbidden have smaller announcement day price increases. There is also evidence of bargaining between the subject firms and the regulators. Proposed combinations with greater potential value are more likely to be approved subject to conditions; i.e., firms are willing to concede more when the stakes appear to be larger.

The paper is divided into sections as follows: Section 1 provides a summary of the legal authority vested in the DGC of the EEC and describes the procedures followed as specified by law; Section 2 describes the data and gives a few examples of market price reactions of individual firms to EEC announcements; Section 3 presents an event study for a comprehensive sample and for sub-samples categorized by size, country, and other pertinent attributes of individual cases; Section 4 interprets the results and concludes.

\section{European control of combinations: a brief summary}

The European Commission's interventions against business combinations are governed by recent regulations, the first one dating back only to 1989. They specify the size and type of combination subject to EEC jurisdiction and the procedures to be followed in the event of an intervention. This section describes the legal context and summarizes some important differences between European and American procedures.

\subsection{The scope of intervention.}

An important novelty introduced by regulation EEC $n^{\circ} 4064 / 89$ (passed in 1989 and first implemented in 1990) is the one shop principle. In general, Pan-European regulations about business agreements and dominant position abuses allow for concurrent enforcement of national regulations. But EEC regulation takes exclusive precedence for mergers and acquisitions of European "dimension." According to article 1.2 of 
$n^{\circ} 4064 / 89$, a combination is considered to be of European dimension when the two following conditions are met:

1. the total world wide gross sales ${ }^{4}$ of all concerned firms exceeds 5 billion euros. ${ }^{5}$

2. the European individual gross sales of at least two of the concerned firms exceeds 250 million euros, unless every concerned firm makes at least $2 / 3$ of its gross sales in a single member State.

Significant alterations were made in 1997 to the basic regulation by the passage of Regulation $n^{\circ} 1310 / 97$. The thresholds were broadened so that a proposed combination would have a European dimension, even if it did not satisfy the original two conditions above, provided that it did satisfy the following four conditions:

1. the total world wide gross sales of all concerned firms exceeds 2500 million euros;

2. the combined gross sales of all the concerned firms exceeds 100 million euros in each of at least three EEC member states;

3. in each of at least three member states satisfying condition (2), the individual gross sales of at least two different firms each exceeds 25 million euros;

4. the individual EEC-wide gross sales of at least two firms each exceeds 100 million euros;

unless every firm makes more than two-thirds of its aggregate EEC-wide sales within the same member state.

These criteria sweep under EEC purview most significant business combinations. They imply that national regulations by the individual member states have been relegated to a role of secondary importance.

\subsection{Juridical Competence.}

The EEC's exclusive authority might explain the favorable reception of these new regulations by major European firms, simply because they shorten the length of anti-trust procedures. The EEC's decisions are final and need the approval of no higher judicial authority. Indeed, there is no appeal other than to a 'tribunal de première instance' (a country court) or to the EU court. This allows the Commission to negotiate remedial actions from a strong position; the firms involved usually wish to avoid a prolonged court appeal of uncertain outcome, (Cf. Winckler and Brunet, 1998, p.14).

\footnotetext{
${ }^{4}$ The original french language regulation specifies the criterion in terms of "chiffres d'affaires" which is translated in the english language version as "turnover." We believe this is the same accounting number as gross sales.

${ }_{5}^{5}$ Originally, the threshold was denominated in ECUs. This changed one-for-one to Euros in 1998.
} 
Here is one of the main differences between European and American combination control systems. The American system stipulates that the authorities (Department of Justice and Federal Trade Commission) must obtain the consent of a judge for every ban, whereas the EEC on its own authority can block what it considers an objectionable combination.

\subsection{Procedure}

Figure 1 depicts the various steps of the European Commission's procedure. A combination must advise the Commission no later than one week after a deal agreement (public announcement of a take over, an exchange offer, or acquisition of control.) There are some noteworthy differences from American procedures:

- Notification to the EEC can be given only after the official signing of a deal agreement.

- European regulators are supposed to maintain full confidentiality about all information received following a notification. Confidentiality is obligatory until the authorities decide to block the operation or allow it to proceed.

- A combination cannot be completed before the initial notification and to take effect it must be declared acceptable after the investigation.

As specified in article 10 of regulation 4064/89, the commission has one month to complete its preliminary analysis; (time runs from the moment it receives complete information). This period is called phase I. It culminates in a decision based mainly the information contained in the notification ${ }^{6}$. Four decisions are possible:

1. the operation does not constitute a combination of European dimension and hence is not subject to review (article 6.1.a of regulation 4064/89);

2. the combination is compatible with the rules of the common market (article 6.1.b of regulation 4064/89) and is therefore approved;

3. although the operation is basically compatible with the rules of the common market, the combination will be permitted only if certain conditions are met (article 6.1 bis of regulation 4064/89, and article 1.5.a of regulation 1310/97);

\footnotetext{
${ }^{6}$ The Commission also sends questionnaires to the clients and suppliers that might be affected.
} 
4. doubts are cast on the proposed combination. A more detailed analysis will be undertaken. This extended investigation is called Phase II (article 6.1.c of regulation 4064/89). The criteria that bring this denouement have never been clarified.

Once the detailed investigation is underway, the Commission has four additional months to complete its investigation and to rule on the compatibility of the combination with European law. At the end of the (up to) four-month period, the Commission may issue three possible rulings:

1. the combination is approved;

2. the combination is approved subject to certain conditions;

3. the combination is unacceptable.

If the combination has already been consummated, the Commission can order the separation of the firms or of the grouped assets, the end of common control, or any action that could restore competition.

The last two outcomes supposedly reflect doubts the Commission has concerning the compatibility of the operation with competition. In such an event, the commission must communicate its objections to the parties involved and provide them the opportunity to present their points of view ${ }^{7}$. As stressed by Winckler and Brunet (1998, p. 65) "such a communication of grievances plays an important part in the procedure, since the Commission can base its final decision only on objections for which the interested parties were given the opportunity to put forward their observations." The interested parties have the right to examine the case file and can demand a hearing ${ }^{8}$.

\footnotetext{
${ }^{7}$ Regulation $\mathrm{n}^{\circ} 4064$ / 89, article 18.1 .

${ }^{8}$ Regulation $n^{\circ} 447$ / 98, relating to notifications, to delays and to hearings, article 13.3.
} 


\section{Our Data}

2.1. Statistics about actions by the DGC (Directorate General for Competition of the European Commission)

Table 1 provides summary information on combinations that notified the EEC since the inception of the regulation in 1990 through the latest month in our data sample, (December, 1999.) The entries after the first line show the number of outcomes by type of decision.

Table 2 lists cases that were subject to extended investigation by the EEC (Phase II). As of December, 1999, 61 proposed mergers and acquisitions were taken through Phase II by the Commission. Among them, twelve were approved without conditions (cf. Table 1), 35 were approved subject to various conditions, and eleven were declared incompatible with EU conditions and were therefore forbidden. Another three cases were resolved by a different type of decision. Figure 2 provides a breakdown of firms by industry.

\subsection{Market price and volume data.}

Stock price and volume data were obtained from Datastream accessed at the Université de Lille II. For announcement dates, three separate sources were checked: Reuters and Bloomberg (through Dexia bank) and, depending on the country, the financial press (Les Echos, Financial times, Wall Street Journal, etc.).

Much information is available on http://www.europa.eu.int/comm/competition, the official DGC web site. These include

- Statistics on interventions by the DGC;

- Current legislative amendments;

- Final decision reports (some of them are even downloadable in *.pdf). 
Because the firms involved were traded on various national exchanges, it was necessary to collect local market information about each exchange and to select a market index (which will be employed in the usual way to construct abnormal returns.) The countries involved, the stock market indexes selected, and the local currencies are listed in Table 3.

\subsection{Firms and cases with available data.}

It usually takes quite a while after the intervention for the EEC to file an official report on its web site. Consequently, we were obliged to restrict our analysis to notifications from 1990 through 1999 inclusive; later cases were mostly incomplete. The total number of notified operations during this period was 1228; (see Table 1.)

Of these 1228 notifications, 1210 final decisions, comprised of 1160 major decisions and 50 "other" decisions ${ }^{9}$, were reached by the end of $1999^{10}$. We study only the major

decisions. Many of the proposed business combinations were among small or closelyheld firms with no readily available market price information, so they could not be included in this study. Our criterion for including a notification in our final sample is straightforward: at least one of the subject firms must be quoted on a national stock exchange. Only 606 of the $1160^{11}$ major decisions, involving 1085 different firms, satisfy this requirement. Four decisions involved firms with insufficient market data prior to the notification, leaving 602 in our final sample. Of these, 308 involved firms domiciled in the European community, 101 involved only non-EEC firms, and 193 pertained to combinations between an EEC and a non-EEC firm. Fifteen of the 1085 firms were delisted prior to the final decision, so only 1070 are complete throughout the EEC examination process. For the final sample of the 602 notifications with available data, Table 3 provides a breakdown by year of notification and by final decision, and for the 1070 individual firms involved, by home country.

\footnotetext{
${ }^{9}$ As described in the footnote of Table 1 .

${ }^{10}$ Eighteen were carried over for resolution into calendar year 2000.

${ }^{11}$ 1990-99 inclusive
} 


\section{Market Response to EEC Regulatory Actions.}

The accepted method for isolating the impact of a particular event on market valuations is the "event" study, which consists of two complementary filters. First, "abnormal" returns are estimated for each individual firm. These are obtained by removing concurrent general market movements and average long-term returns. Second, abnormal returns are averaged across firms for calendar dates relative to the event date. Since the origination of events studies by Fama, et. al, [1969], there have been many variations on this basic theme, all consisting of statistical procedures designed to measure the event more precisely. In the sequel below, we employ several variants in an effort to assure that the results are robust.

\subsection{Price and Volume Charts for Selected Firms.}

To illustrate the difficulty of discerning any pattern for an individual firm (and thus to show the importance of event study filtering), Figure 3 provides price and volume time series for a few large and well-known firms around the time of an European intervention with respect to a proposed merger. The period of DGC intervention is indicated by the arrows (from the initial notification to the final decision.) All of these illustrated cases extended through Phase II. In general, individual prices and volume display the usual noise throughout the sample. However, there appear to be some discernable common differences between EEC intervention and non-intervention periods. Four of the eight cases illustrated underwent price declines during intervention even though their general price trends over the entire sample were mostly positive. One can almost be persuaded also that there is a discernable increase in trading volume during intervention (though there are clearly many other periods with abnormally high trading activity.)

\subsection{Estimation of Normal Returns for Individual Firms.}

The first step in isolating the effect of an event is to construct a model for "normal" returns; i.e., individual firm returns that would have occurred in the absence of the event. We decided to try three different procedures, each of which has appeared many times in other papers and each possessing various merits and possible problems. These are (1) the 
simple market model; (2) the market model with parameters estimated by the method of Scholes and Williams [1977]; and (3) the constant mean return model.

The simple market model is

$$
\mathrm{R}_{\mathrm{j}, \mathrm{t}}=\alpha_{\mathrm{j}}+\beta_{\mathrm{j}} \mathrm{R}_{\mathrm{M}, \mathrm{t}}+\varepsilon_{\mathrm{j}, \mathrm{t}},
$$

where $R_{j, t}$ is the observed return for firm $j$ on day $t$ (in local currency), $R_{M, t}$ is a concurrent local country stock market index, $\alpha_{\mathrm{j}}$ and $\beta_{\mathrm{j}}$ are, respectively, the estimated OLS regression intercept and slope, and $\varepsilon_{\mathrm{j}, \mathrm{t}}$ is a regression residual. The returns are all continuously-compounded; (i.e., log price relatives.)

The regression estimates were computed using 200 daily observations from a period prior to the initial announcement. The 30 days immediately preceding the announcement event window were excluded since they might be contaminated by information leakage. Eleven observations constitute our event window, five days before and five days after the event date, which is day zero. Hence, the regression estimation period is -235 through day -36 relative to the announcement date. The estimation was done with these observations only, even for events other than the initial announcement (such as the final resolution disclosure), because data subsequent to the initial announcement are possibly abnormally influenced by the proposed combination.

Table 4 presents regression summary statistics for the 1085 different individual firms in the sample. These regressions do not adhere very well to the spherical Gaussian specification. The disturbances are significantly non-normal in a large majority of instances (which is a typical situation with financial returns), and there is also a lesser though still significant amount of heteroscedasticity and autocorrelation. These are good reasons to try alternative statistical approaches. On the other hand, the explanatory power is quite good with an average R-square more than $30 \%$, somewhat higher than in the usual market model regression for an individual firm. This probably reflects the larger firm sizes stipulated by EEC regulations for examination. 
The Scholes/Williams method is similar except that the coefficients in the market model take account of asynchronous trading. The constant mean return model computes for each firm $j$ the average return $\bar{R}_{j}$ in the 200-day estimation period and then estimates abnormal returns during the event window by

$$
\varepsilon_{\mathrm{j}, \mathrm{t}}=\mathrm{R}_{\mathrm{j}, \mathrm{t}}-\overline{\mathrm{R}}_{\mathrm{j}}
$$

\subsection{Abnormal Returns Around Announcement Dates.}

Our first results, shown in Figure 4, depict cumulative average abnormal returns (CAAR) for all firms in the sample for two event dates and for three different methods of estimating the abnormal returns. ${ }^{12}$ The cumulative average abnormal return is computed from the regression (1) residuals or with the mean deviations (2), first averaging across firms relative to the announcement dates and then accumulating the averages from the day prior to the event window; i.e., for day $\mathrm{T}$ relative to the announcement date, $\mathrm{t}_{\mathrm{j}}$, for firm $j$

$$
\operatorname{CAAR}_{T}=\sum_{\tau=-5}^{\mathrm{T}} \frac{1}{\mathrm{~N}} \sum_{\mathrm{j}=1}^{\mathrm{N}} \varepsilon_{\mathrm{j}, \mathrm{t}_{\mathrm{j}}+\tau}
$$

where $\mathrm{N}$ is the number of firms in the sample or sub-sample. Note that the average abnormal returns can be cumulated over time by simple addition because they are continuously compounded.

As perhaps would be expected, a sizeable price movement occurs on the first announcement of a proposed business combination by the companies. It exceeds two percent on the day of the announcement and the two preceding days. Evidently, there is leakage or insider trading in some cases. (Recall at this point that both the bidder and target firms along with joint ventures are included here.)

\footnotetext{
12 The p-values plotted were obtained using the method in Boehmer, et. al., [1991], with an added assumption that the abnormal returns were independent over time for each firm.
} 
The notification date occurs no later than a week after the first announcement date. There is a small price increase prior to notification, perhaps because some notifications occur within a day or two of the first announcement. Nothing much happens within the few days after notification and we will not report anything around this date from here on.

Since the three methods of computing cumulative abnormal returns give similar results, we will henceforth only plot those obtained with the market model, but will provide some additional robustness checks in a later section.

\section{2.a. Announcement Effects for Bidders, and Targets, and Joint Ventures.}

For each of business combination except those specifically designated as joint ventures, we assigned the role of "bidder" to one firm and the role of "target" to a second firm. If more than two firms were involved, all except one were "targets." Usually, the notification to the European Commission explicitly states which firm is the bidder. If this were not true in a particular operation, we consulted the financial press and made a best effort to ascertain each firm's role.

Figure 5 depicts the results. In Panel $\mathrm{A}$, the event is the initial announcement of the combination. Not surprisingly given past empirical studies of mergers, ${ }^{13}$ there is a much larger abnormal price increase among target firms than among bidders. Both are statistically significant on the announcement date and thereafter. Target firms actually have significant abnormal positive performance up to five days prior to the announcement and bidder firms also are abnormally positive on just the day before. Evidently, there is leakage in some countries about the pending combination. Joint ventures, however, actually show small but significant negative abnormal performance both prior to and after the announcement.

In Panel B of Figure 5, cumulative average abnormal returns for firms subjected to Phase II are shown around the announcement of the investigation. Clearly, this is bad news for

\footnotetext{
${ }^{13}$ See, for example, the review paper by Jensen and Ruback [1983] and the other studies in the same special issue of the Journal of Financial Economics.
} 
a business combination and somewhat worse news for targets than for bidders, on average. Due to the small sample size of firms subjected to Phase II, however, there is not much statistical significance (except for the joint venture group several days after the Phase II investigation announcement.)

Figure 5, Panels $\mathrm{C}$ and $\mathrm{D}$ depict abnormal returns around the announcement of the final decisions by the EEC. When the investigation is concluded after Phase I, the announcement is generally good news because the proposed combinations is usually allowed to proceed, though sometimes subject to conditions. Final decisions after a Phase II investigation also are favorable in the majority of cases (Cf. Table 1), since most are allowed to proceed either as proposed or subject to some conditions. Only eleven of the 61 Phase II investigations resulted in outright prohibition.

\section{2.b. Announcement Effects by Home Country of Firms.}

Some suspicion about EEC motives has been mentioned in the non-European press. Do EEC anti-combinations activities differentially impact non-European firms, perhaps reflecting de facto protectionism of European rivals? To shed some light on this issue, Figure 6 divides the sample into individual firms by domicile, Europe and Non-Europe. In this Figure, the plots are by firm, not by the business combination; hence, if the combination were between a European firm and a non-European firm, the two parties to that combination would be plotted separately.

First, Panel A of Figure 6 shows a dramatically higher announcement date price increase for non-European firms, whether they are bidders or targets. It is roughly double the price increase experienced by European firms. This is quite surprising in that European regulations make no distinction according to home country. There are, of course, more European firms with a "European dimension" to their activities, but there is no regulation pertaining to the price rise around the initial announcement. Panel B reveals that the initial announcement difference between Non-EEC and EEC firms is mainly attributable to targets. Bidder firms have quite similar price movements, regardless of domicile, but 
non-EEC targets have more than a $12 \%$ abnormal price increase around the initial announcement, double that of European targets.

Phase II proceedings are bad news for both EEC and non-EEC firms; see Panel C of Figure $6 .^{14}$ The price drop right around the Phase II investigation announcement is actually larger for EEC firms, but the sample sizes here are small, so this pattern may not be statistically reliable. The final decisions, either termination after Phase I or after Phase II, (Figure 6, Panel D) show similar patterns, though in both cases non-EEC firms have somewhat higher abnormal returns accumulated over the event window.

Overall, we see nothing in these figures to indicate that the European Commission is discriminating against non-EEC firms in business combinations. If anything, the Commission's regulatory actions have had a more severe impact on the prices of European firms, though there is not much of a statistically significant difference. ${ }^{15}$

\section{2.c. Announcement Effects as Predictions of Final Outcome.}

On the initial announcement of a proposed business combination, market participants much surely consider the likely outcome of regulatory action. But it seems possible also that the regulators themselves might be influenced by the initial price response to a proposed deal. For example, suppose that there really is on occasion some monopoly rents to be gained from a merger; if the market assesses this possibility correctly, there should be a larger than average price rise of both bidder and target around the initial announcement. But if European regulators are doing a good job, this should be associated with a higher probability of a Phase II investigations and subsequent prohibition.

Figure 7, Panel A, seems consistent with this idea. Firms that eventually proceed to an in-depth Phase II investigation by the regulators have substantially larger price increases on the initial announcement date. Perhaps regulatory suspicion is aroused by the

\footnotetext{
${ }^{14}$ Ellert [1976] also found a negative reaction to the announcement that the merger of two U.S. firms was to be challenged by American regulators. We thank J. Fred Weston for reminding us of Ellert's work.

15 This issue will be taken up again in a multivariate context in section 4 below.
} 
announcement date return or, alternatively, the potential for monopoly rents is independently determined by the regulators to be worthy of a Phase II investigation.

In Panel B of Figure 7, we separate firms by the final outcome after either Phase I or II and plot their initial announcement abnormal returns. The amazing result here is that firms which will ultimately be prohibited from merging have no initial positive abnormal return on the initial announcement date. It appears that the market can predict, even as early as the initial announcement, that a proposed combination will be disallowed. In contrast, firms that are eventually allowed to proceed, with or without conditions, show the usual significant price increases around the initial announcement.

\section{2.d. Announcement Effects by Eventual Outcome.}

In Figure 8, Panel A, the cumulative abnormal return is plotted by the type of decision rendered by EEC regulators around the announcement date of the decision. Combinations which are prohibited fare relatively badly at this time, as one would expect. In contrast, combinations which may proceed, either unrestricted or with conditions, show positive price movements (though they are not statistically significant in the case of the unrestricted cases.)

The fact that the decision announcement has a noticeable impact on prices implies that the type of decision is something of a surprise. Panel B of Figure 8 supports this view because it shows that firms subject to Phase II investigations undergo price declines around the Phase II announcement, regardless of the eventual outcome. However, the impact is larger on the few days around the announcement for cases which will ultimately be prohibited.

\subsection{Multivariate Analyses}

To this point, we have mainly relied on a graphical presentation of price reactions around various announcements. This is an unavoidably univariate procedure. But there are important questions whose answers seem likely to be provided only by a multivariate 
approach. For example, are there several variables influencing the magnitude of the price movement around the initial announcement of the proposed combination? Is it possible to identify variables that influence the probability of a Phase II investigation? What are the determinants of a particular decision (prohibition, authorization, approval subject to conditions, referral to a member state)? In this section, we employ standard multivariate methods in an effort to shed light on these interesting questions.

\section{3.a. The Price Impact of the Initial Announcement}

Possible variables that might influence the level of an individual firm's $\mathrm{CAR}^{16}$ around the initial announcement date are the firm's role (e.g., target or bidder), home country, size, and assuming that the market can forecast with at least a modicum of accuracy, the subsequent type of EEC investigation and its eventual outcome. This suggests the following cross-sectional regression:

$$
\begin{aligned}
\text { CAR }_{\mathrm{i}} & =\beta_{0}+\beta_{1} \text { TARGET }_{\mathrm{i}}+\beta_{2} \text { BIDDER }_{\mathrm{i}}+\beta_{3} \text { NEEC }_{\mathrm{i}}+\beta_{4} \mathrm{MV}_{\mathrm{i}}+ \\
& +\beta_{5} \text { PhII }_{\mathrm{i}}+\beta_{6} \text { PROHIB }_{\mathrm{i}}+\beta_{7} \text { COND }_{\mathrm{i}}+\beta_{8} \mathrm{REF}_{\mathrm{i}}+\varepsilon_{\mathrm{i}}
\end{aligned}
$$

where:

- the firm's role is coded by the dummy variables TARGET and BIDDER (if TARGET and BIDDER are both equal to zero, the combination is a joint venture);

- the home country is coded by the dummy variable NEEC which is 1.0 for a nonEuropean firm and 0 otherwise;

- $\mathrm{MV}$ is the logarithm of the firm's market value on the last day of the estimation window;

- $\quad$ PhII is 1.0 if the combination will undergo Phase II investigation and 0 otherwise;

- the eventual outcome is coded by the dummy variables PROHIB (for prohibition), COND (for approval subject to conditions) and REF (for referral to a member state). If they are all equal to zero, the combination is authorized outright.

The results of OLS estimation are presented in Table 5. As found in many previous studies of mergers and acquisitions, the firm's role has a large impact on the CAR. Being

\footnotetext{
${ }^{16} \mathrm{CAR}$, the cumulative abnormal return for an individual firm is to be distinguished from CAAR, the cumulative average abnormal return of firms in a particular sub-class.
} 
a target or a bidder has a positive and statistically significant ${ }^{17}$ price impact as compared to being involved in a joint venture, but the impact for a target is almost seven times larger than for a bidder.

Non-European firms have a significantly larger price increases around the initial announcement. This is quite puzzling since the regression controls for other possible differences between the European and non-European sub-samples such as size, firm role, investigation type, and eventual outcome. One possible explanation involves a subtle distinction between the typical corporate organizational forms within and outside Europe. Many European combinations in the sample are between subsidiaries of holding companies. But only the parent companies, not the subsidiaries, are quoted on European stock exchanges, so the price impact cannot be observed for the subsidiary in isolation. This is less frequently the case for non-European combinations. Hence, the initial announcement effect could be attenuated for European firms on average because it represents a smaller fraction of the quoted companies' total assets.

To check this possibility, we eliminated from the sample all cases where one of the firms was a holding company and then plotted the CAAR corresponding to Figure 6. The results, shown in Figure 9, indicate a clear dilution effect from holding companies since the CAAR rises significantly higher when they are excluded. However, contrary to our conjecture that holding companies explain the difference between EEC and non-EEC CAARs around the initial announcement, there remains a large difference after they are excluded. At this point, we have no explanation for the puzzle.

Firm size is highly significant and negative. The smaller the firm, the larger the price increase on the announcement date, ceteris paribus. Although the coefficient applies to both targets and bidders, (since there is a dummy variable included for each), it could be influenced mainly by larger takeover premiums offered to smaller targets. When a target is on the small side, perhaps the bidder pays less attention to the winner's curse.

\footnotetext{
${ }^{17}$ At $10 \%$ level for bidders and at $1 \%$ level for target.
} 
Neither the eventual type of investigation (Phase I or II) nor the final EEC decision are statistically significant. This conflicts with Figure 7, Panels A and B, which depict differences among the initial announcement effects with respect to both of these events. If the Table 5 multivariate results are valid, the patterns in Figure 7 must have been induced by a spurious correlation between the investigation type or the decision and the one of the other variables, such as size or home country. In an effort to shed more light on this question, the next sub-sections continue with alternative approaches.

\section{3.b. The Probability of a Phase II Investigation.}

The successful prediction of a Phase II investigations would be acutely interesting to investors and of course to the subject firms. So we have estimated the following Logit model:

$$
\mathrm{PhII}_{\mathrm{i}}=\mathrm{f}\left(\beta_{0}+\beta_{1} \mathrm{NEEC}_{\mathrm{i}}+\beta_{2} \mathrm{CAR}_{\mathrm{i}}+\beta_{3} \mathrm{MV}_{\mathrm{i}}\right)
$$

where :

- $\mathrm{PhII}$ is 1.0 if the combination proceeds to Phase II, otherwise zero;

- $\mathrm{f}()$ is the logistic function;

- NEEC is 1.0 if the firm is not European, otherwise zero;

- CAR is the cumulated abnormal return at the end of the announcement date window;

- MV is logarithm of the firm's market value on the last day of the estimation window;

Maximum likelihood estimates of coefficients are reported in Table 6 along with asymptotic estimates of t-statistics and p-values. In addition, we decided to produce a resampling distribution of the coefficients because the fraction of firms proceeding to Phase II is relatively small and logit models are known to converge slowly under such conditions. The bootstrap p-values in the last column of Table 6 indicate the fractile of the resampling distribution corresponding the coefficient point estimate.

The probability of undergoing a Phase II investigation increases with firm size; significance level about $7 \%$ and $4 \%$ for asymptotic and bootstrap, respectively. This is not too surprising because the European Commission is a political entity and larger proposed combinations receive more public attention. 
The NEEC non-European dummy is positive but not statistically significant. From 1990 through 1999, European firms were slightly less frequently subjected to a Phase II investigation than were firms from outside the EEC, but the difference was statistically marginal. If the coefficient had been significant, one could have concluded that the European Commission discriminates, for political or protectionist reasons, against combinations of non-European origin. However, such a conclusion is currently unwarranted and it appears we will have to await a larger sample from future Phase II investigations to settle the issue one way or the other.

The CAR's positive coefficient is marginally significant at an asymptotic (bootstrap) level of about 14\% (2\%). This is consistent with Figure 7, Panel A. The larger the CAR at the announcement date, the higher the probability of undergoing a Phase II investigation.

\section{3.c. Predicting the Outcome of EEC Regulatory Intervention.}

The parties involved and the investing public await the EEC's final decision with anxiety and trepedition. Can the decision be predicted in advance? In an effort to answer this question, we estimated the following multinomial Logit model ${ }^{18}$ :

$$
\mathrm{DEC}_{\mathrm{i}}=\mathrm{f}\left(\beta_{0}+\beta_{1} \mathrm{NEEC}_{\mathrm{i}}+\beta_{2} \mathrm{CAAR}_{\mathrm{i}}+\beta_{\mathrm{i}} \mathrm{MV}_{\mathrm{i}}\right)
$$

where DEC is equal to 1 for prohibition, 2 for approval subject to conditions and 3 for outright authorization. The other variables are the same as in model (5).

Maximum likelihood estimation results are presented in Table 7. Two coefficients are statistically significant. The first is size; larger firms have a higher probability of authorization with conditions as compared to prohibition. Perhaps larger firms have a better bargaining position with EEC regulators because of political connections, more capable legal advice, or simply greater ability to present persuasive arguments in favor of the proposed combination. 
The second significant coefficient is for the initial announcement CAR. A larger announcement CAR predicts a higher probability that the final decision will be authorization subject to conditions as compared to prohibition. This seems quite sensible in that a potentially large gain in economic value, as evidenced by a positive announcement CAR, provides motivation to reach a settlement with European regulators. Conversely, if the proposed combination appears unlikely to be valuable, there is less reason to resist outright prohibition by arguing or granting concessions.

In contrasting outright authorization against prohibition, both MV and CAR have the same positive coefficients, but neither is statistically reliable. An enhanced sample size should determine whether size and value creation (the latter as measured by the announcement $\mathrm{CAR}$ ) prompt EEC regulators to allow the combination to proceed.

The domicile of the firm, as measured by the dummy variable NEEC, is not significant in either contrast. Hence, there is no evidence that non-European firms are ultimately treated differently. This conclusion must be tempered, however, because we have no evidence on the extent or the severity of the conditions required before a combination is allowed. It is possible that non-European firms must agree to more onerous conditions ${ }^{19}$ or vice versa.

\subsection{Robustness Checks.}

To obtain the results in section 3, market model regressions were done for each country in local currency returns. Then the abnormal returns were translated into a common currency, the U.S. Dollar, at concurrent exchange rates. To investigate the role that currency denomination plays in the results, we altered this approach in two ways. First, we recomputed the market model regressions by first converting the local currency returns into dollar returns. Second, we re-plotted some of the figures using local currency abnormal returns.

\footnotetext{
${ }^{18}$ To simplify the comparisons, we have not included the small number of cases whose final decision was referral to a member state.

${ }^{19}$ For example, the EEC regulators offered to approve the General Electric/Honeywell merger if, inter alia, GE would divest its aircraft financing subsidiary. GE refused and the merger was prohibited.
} 
Figure 10, Panel A depicts the cross-sectional distribution of explanatory power (Rsquare) from market model regressions denominated in local currencies and in U.S. dollars. The regressions using dollar returns are have slightly less explanatory power. Panel B of Figure 10 plots cumulative abnormal returns corresponding to Figure 4, Panel A in both local currencies and dollars. The plots are virtually indistinguishable.

Consequently, it appears that currency has had little influence, probably because of the short-term nature of the daily stock return data and the low correlation between local currency returns and exchange rate fluctuations.

The second issue about robustness involves suspensions of trading around announcement dates. We noticed in the data that the volume of trading was often zero, particularly on the initial announcement data of the combination. This is no doubt mostly attributable to trading suspensions occasioned by the unusual information event. To ascertain whether this had a material impact on the results, we deleted all cases of zero trading volume and re-plotted some of the cumulative abnormal returns. Figure 11 shows again that this had little perceptible influence on the results. 


\section{Summary and Conclusions.}

Government regulation of business combinations is becoming an international phenomenon. Over the past decade, for example, regulators from the European Commission have increasingly intervened in proposed mergers and acquisitions, even for entirely non-European combinations fully approved by their home countries. EEC regulators have the power to block combinations from virtually any country if the subject companies do significant business within Europe. It likely that other jurisdictions will reciprocate and some, such as the U.S., have already done so.

This regulatory trend poses obvious potential difficulties for the efficient organization of global industry. Imagine that on some future date there are, say, five separate regulatory blocks, each with its own approach to approving or prohibiting business arrangements. To the extent regulators act independently, the probability of simultaneous approval by all regulatory blocks could be small, even if authorization is likely within each single jurisdiction.

To our knowledge, this paper is the first to present evidence on the market reactions to EEC regulatory events. We first describe the regulatory process in Europe, which conforms to a strict timetable and thus allows accurate measurement of market price reaction to regulatory decisions. According to current EEC regulatory law, only the larger proposed business combinations are subject to intervention. Intervention then proceeds in two stages; Phase I provides for a preliminary investigation with four possible outcomes: not subject to EEC intervention, approval, approval subject to conditions, and further investigation. Most investigations terminate without further investigation. However, a significant number of proposals are subjected to a more thorough examination, called Phase II, which terminates definitively in approval, approval subject to conditions, or prohibition.

We examined the abnormal market price movements of 1085 firms from 19 countries as they moved through the EEC regulatory process. As in many past studies of business 
combinations, target firms had very sizeable price increases on the initial announcement date. Bidder firms and firms engaged in joint ventures had smaller announcement effects. The market is well aware on the announcement date that regulatory intervention is possible. The announcement price movement, in fact, has some power in forecasting the likelihood of a Phase II extended investigation and in forecasting the final EEC regulatory decision.

Non-European firms have larger announcement date price increases but they are only slightly more likely to be extensively investigated by EEC regulators. In terms of the final regulatory decision, there is no evidence that non-European firms are treated differently. Consequently, at this point there is no statistical support for the oft-stated suspicion outside Europe that the EEC regulators have a less laudable objective; viz., to protect European firms from foreign competitors.

Not surprisingly, there are market price movements around the terminations of both the Phase I and Phase II investigations. Proceeding to Phase II is bad news. Outright prohibition is bad news. Approval subject to conditions is relatively good news; this seems to suggest that a bargaining agreement between the regulators and the firms involved, which determine the acceptability conditions (such as divestitures of certain subsidiaries) is more likely when the combination promises to create substantial value.

The number of proposed business combinations investigated by EEC regulators has been increasing slowly since 1990. Our sample to this point is still relatively small, but within a few years many of the conclusions here should be either verified or disconfirmed with a higher level of statistical reliability. 


\section{References}

Aktas, Nihat, Eric de Bodt, Michel Levasseur, and André Schmitt, 2001, The emerging role of the European Commission in merger and acquisition monitoring: The Boeing/McDonnell Douglas case, (forthcoming, European Financial Management.)

Aktas, Nihat, Eric de Bodt, and Michel Levasseur, 2001, The information impact of the European Commission interventions in the field of merger and acquisition monitoring, (working paper, Ecole Supérieure des Affaires, Université de Lille 2, April.)

Boehmer, Ekkehart, Jim Musumeci, and Annette B. Poulsen, 1991, Event-study methodology under conditions of event-induced variance, Journal of Financial Economics 30, 2 (December), 253-272.

Ellert, James C., 1976, Mergers, antitrust law enforcement and stockholder returns, Journal of Finance 31, 2 (May), 715-732.

Fama, Eugene F., Lawrence Fisher, Michael C. Jensen, and Richard Roll, 1969, The adjustment of stock prices to new information, International Economic Review 10, 1 (February), 1-21.

Jensen, Michael C., and Richard S. Ruback, 1983, The market for corporate control, Journal of Financial Economics 11, 1-4 (April), 5-50.

Priest, George L., and Franco Romani, 2001, The GE/Honeywell Precedent, The Wall Street Journal, (June 20), A-18.

Scholes, Myron, and Joseph Williams, 1977, Estimating betas from nonsynchronous data, Journal of Financial Economics 5, 3 (December), 309-327.

Wall Street Journal, 2000, Regulators Sink EMI-Time Warner Deal, (October 6), A-3.

Winckler, A., and F. Brunet (under the direction of), 1998, La pratique communautaire du contrôle des concentrations: Analyse juridique, économique et comparative Europe, Etats-Unis et Japon, éd De Boeck Université, $2^{\text {nd }}$ edition. 
Table 1

\section{EEC Regulatory actions concerning business combinations}

21 September 1990 - 31 December 1999

\begin{tabular}{|c|c|c|c|c|c|c|c|c|c|c|c|}
\hline & 90 & 91 & 92 & 93 & 94 & 95 & 96 & 97 & 98 & 99 & Total \\
\hline Number of cases notifying the EEC & 12 & 63 & 60 & 58 & 95 & 110 & 131 & 172 & 235 & 292 & 1228 \\
\hline Cases withdrawn - Phase I & & & 3 & $\mathbf{1}$ & 6 & 4 & 5 & 9 & 5 & 7 & 40 \\
\hline Termination after Phase I & 7 & 55 & 57 & 54 & 86 & 102 & 118 & 131 & 229 & 260 & 1099 \\
\hline Outside EEC jurisdiction & 2 & 5 & 9 & 4 & 5 & 9 & 6 & 4 & 6 & 1 & 51 \\
\hline Approved without conditions & 5 & 47 & 43 & 49 & 78 & 90 & 109 & 118 & 207 & 236 & 982 \\
\hline Approved subject to conditions & & 3 & 4 & & 2 & 3 & & 2 & 12 & 19 & 45 \\
\hline Other decisions after Phase $\mathrm{I}^{20}$ & & & 1 & 1 & 1 & & 3 & 7 & 4 & 4 & 21 \\
\hline Phase II proceedings initiated & & 6 & 4 & 4 & 6 & 7 & 6 & 11 & 12 & 20 & 76 \\
\hline Cases withdrawn - Phase II & & & & 1 & & & 1 & & 4 & 5 & 11 \\
\hline Decision after Phase II & & 5 & 4 & 3 & 5 & 7 & 7 & 11 & 9 & 10 & 61 \\
\hline Approved & & 1 & 1 & 1 & 2 & 2 & 1 & 1 & 3 & 0 & 12 \\
\hline Approved subject to conditions & & 3 & 3 & 2 & 2 & 3 & 3 & 7 & 4 & 8 & 35 \\
\hline Prohibited & & 1 & & & 1 & 2 & 3 & 1 & 2 & 1 & 11 \\
\hline${\text { Other decisions of Phase } \text { II }^{21}}$ & & & & & & & & 2 & & 1 & 3 \\
\hline Other decisions $^{22}$ & 1 & 2 & 2 & 4 & 1 & 3 & 4 & 6 & 14 & 13 & 50 \\
\hline
\end{tabular}

\footnotetext{
${ }^{20}$ Partial or full referral to an individual EEC member state

${ }^{21}$ Partial referral to an individual EEC member state or restoration of effective competition

${ }^{22}$ Previous decision revoked, imposition of fines, or relief from prior suspension
} 
Table 2

\section{Resolution of combinations subjected to Phase II Investigations}

Panel A. Cases approved without conditions - Art. 8(2).

\begin{tabular}{|l|l|l|l|}
\hline Concerned parties & Products (sectors) & $\begin{array}{l}\text { Beginning of phase } \\
\text { II }\end{array}$ & Final Decision \\
\hline Tetra Pak / Alfa Laval & Packaging & $03 / 19 / 91$ & $07 / 19 / 91$ \\
\hline Mannesman / Hoesch & Steel tubing and instruments & $07 / 14 / 92$ & $11 / 12 / 92$ \\
\hline Pilkington / Techint / SIV & Steel tubing & $09 / 02 / 93$ & $12 / 21 / 93$ \\
\hline Mannesman / Valourec / Ilva & Steel tubing & $09 / 20 / 93$ & $01 / 31 / 94$ \\
\hline $\begin{array}{l}\text { Thyssen Stahl / Krupp / Riva / } \\
\text { Falck / Tadfin / AST }\end{array}$ & Smelting & $10 / 21 / 94$ & $12 / 21 / 94$ \\
\hline Siemens / Italtel & Telecommunications & $10 / 14 / 94$ & $02 / 17 / 95$ \\
\hline Mercedes-Benz / Kässbohrer & Busses & $10 / 14 / 94$ & $02 / 14 / 95$ \\
\hline Shell / Montecatini & Chemicals & $/$ & $04 / 24 / 96$ \\
\hline $\begin{array}{l}\text { Coca Cola / Amalgated } \\
\text { Beverages GB }\end{array}$ & Soft drinks & $13 / 09 / 96$ & $01 / 22 / 97$ \\
\hline TKS / ITW Signode / Titan & Manufacture of metal & $12 / 22 / 97$ & $05 / 06 / 98$ \\
\hline $\begin{array}{l}\text { Price Waterhouse / Coopers \& } \\
\text { Lybrand }\end{array}$ & Financial auditing & $01 / 21 / 98$ & $05 / 20 / 98$ \\
\hline Enso / Stora & Manufacture of paper & $07 / 31 / 98$ & $11 / 25 / 98$ \\
\hline
\end{tabular}

Panel B. Cases approved subject to conditions - Art. 8(2).

\begin{tabular}{|c|c|c|c|}
\hline Concerned parties & Products (sectors) & $\begin{array}{l}\text { Beginning of } \\
\text { phase II }\end{array}$ & Final Decision \\
\hline Alcatel / Telettra & Telecommunications & $01 / 21 / 91$ & $04 / 12 / 91$ \\
\hline Magnetti Marelli / CEAC & Batteries & $01 / 21 / 91$ & $05 / 29 / 91$ \\
\hline Varta / Bosch & Automotive batteries & $04 / 12 / 91$ & $07 / 31 / 91$ \\
\hline Accor/ Wagon-Lits & Tourism & $12 / 16 / 91$ & $04 / 28 / 92$ \\
\hline Nestle / Perrier & Food and Beverages & $03 / 25 / 92$ & $07 / 22 / 92$ \\
\hline Du Pont de Nemours / ICI & Nylon Fiber & $06 / 03 / 92$ & $09 / 30 / 92$ \\
\hline $\begin{array}{l}\text { KNP / Bürhmann-Tetterode / } \\
\text { VRG }\end{array}$ & Paper & $01 / 18 / 93$ & $05 / 04 / 93$ \\
\hline Kali \& Salz / Mdk / Treuhand & Fertilizer & $08 / 16 / 93$ & $12 / 14 / 93$ \\
\hline P\&G / VP Schickedanz & Paper products & $02 / 17 / 94$ & $06 / 21 / 94$ \\
\hline Shell / Montecatini & Chemicals & $02 / 07 / 94$ & $06 / 08 / 94$ \\
\hline Orkla / Volvo & Alcoholic Beverages & $05 / 23 / 95$ & $09 / 20 / 95$ \\
\hline ABB / Daimler Benz & Ferrous metals & $06 / 23 / 95$ & $10 / 18 / 95$ \\
\hline RTL / Veronica / Endemol & Radio and television & $05 / 22 / 95$ & $07 / 17 / 96$ \\
\hline $\begin{array}{l}\text { Crown Cork \& Seal / Carnaud } \\
\text { Metalbox }\end{array}$ & Food packaging & $07 / 25 / 95$ & $03 / 23 / 96$ \\
\hline Kimberly-Clark / Scott & Paper products & $09 / 12 / 95$ & $01 / 16 / 96$ \\
\hline Sandoz / Ciba-Geigy & Pharmaceuticals & $05 / 02 / 96$ & $07 / 17 / 96$ \\
\hline $\begin{array}{l}\text { Anglo American Corporation / } \\
\text { Lonrho }\end{array}$ & Precious metal production & $12 / 16 / 96$ & $04 / 24 / 97$ \\
\hline $\mathrm{BT} / \mathrm{MCI}$ (II) & Telecommunications & $01 / 30 / 97$ & $05 / 14 / 97$ \\
\hline $\begin{array}{l}\text { Boeing / McDonnell } \\
\text { Douglas }\end{array}$ & Aircraft & $03 / 19 / 97$ & $07 / 30 / 97$ \\
\hline $\begin{array}{l}\text { The Coca Cola Company / } \\
\text { Carlsberg }\end{array}$ & Soft drinks & $05 / 02 / 97$ & $09 / 11 / 97$ \\
\hline Guinness / Grand Metropolitan & Foods & $06 / 20 / 97$ & $10 / 15 / 97$ \\
\hline Siemens / Elektrowatt & Electrical Products & $07 / 29 / 97$ & $11 / 18 / 97$ \\
\hline VEBA / Degussa & Specialized chemicals & $09 / 03 / 97$ & $12 / 03 / 97$ \\
\hline $\begin{array}{l}\text { Hoffmann-La Roche / } \\
\text { Boehringer Mannheim }\end{array}$ & Manufacture of medicinal products & $10 / 02 / 97$ & $02 / 04 / 98$ \\
\hline Agfa - Gevaert / Du Pont & $\begin{array}{l}\text { Manufacture of photographic } \\
\text { chemical material }\end{array}$ & $10 / 09 / 97$ & $02 / 11 / 98$ \\
\hline Worldcom / MCI & Telecommunications & $03 / 03 / 98$ & $07 / 08 / 98$ \\
\hline Skanska / Scancem & Manufacture of mineral products & $07 / 14 / 98$ & $11 / 11 / 98$ \\
\hline Rewe / Meinl & Retail sales & $09 / 28 / 98$ & $02 / 03 / 99$ \\
\hline $\begin{array}{l}\text { Danish Crown / Vestjyeske } \\
\text { Slagterier }\end{array}$ & Agricultural service activities & $11 / 06 / 98$ & $03 / 09 / 99$ \\
\hline
\end{tabular}




\begin{tabular}{|l|l|l|l|}
\hline BT / AT\&T & Telecommunications & $12 / 03 / 98$ & $03 / 30 / 99$ \\
\hline Exxon / Mobil & Oil & $06 / 09 / 99$ & $09 / 29 / 99$ \\
\hline BP Amoco / Atlantic Richfield & Oil & $06 / 10 / 99$ & $09 / 29 / 99$ \\
\hline Telia / Telenor & Telecommunications & $06 / 15 / 99$ & $10 / 13 / 99$ \\
\hline Sanitec / Sphinx & Manufacture of furniture & $08 / 03 / 99$ & $12 / 01 / 99$ \\
\hline Allied Signal / Honeywell & $\begin{array}{l}\text { Manufacture of aircraft and } \\
\text { spacecraft }\end{array}$ & $08 / 30 / 99$ & $12 / 01 / 99$ \\
\hline
\end{tabular}

Panel C. Cases resulting in Prohibition - Art. 8(3).

\begin{tabular}{|l|l|l|l|}
\hline Concerned parties & Products (sectors) & $\begin{array}{l}\text { Beginning of phase } \\
\text { II }\end{array}$ & Final Decision \\
\hline $\begin{array}{l}\text { Aerospatiale / Alenia / de } \\
\text { Havilland }\end{array}$ & Manufacture of aircraft and spacecraft & $06 / 12 / 91$ & $10 / 02 / 91$ \\
\hline MSG Media Service & Telecommunications & $07 / 18 / 94$ & $11 / 09 / 94$ \\
\hline RTL / Veronica / Endemol & Radio and television & $05 / 22 / 95$ & $09 / 20 / 95$ \\
\hline Nordic Satellite Distribution & Radio and television & $03 / 24 / 95$ & $07 / 19 / 96$ \\
\hline Gencor / Lonhro & Non-ferrous metals & $12 / 20 / 95$ & $04 / 24 / 96$ \\
\hline Kesko / Tuko & Retail sales & $07 / 26 / 96$ & $11 / 20 / 96$ \\
\hline $\begin{array}{l}\text { Saint-Gobain / Wacker- } \\
\text { Chemie / NOM }\end{array}$ & Production of abrasive products & $07 / 31 / 96$ & $12 / 04 / 96$ \\
\hline Blokker / Toys « R \& Us & Retail sales (Toys) & $02 / 21 / 97$ & $06 / 26 / 97$ \\
\hline $\begin{array}{l}\text { Deutsche Telekom / } \\
\text { Betaresearch }\end{array}$ & Radio and television & $01 / 29 / 98$ & $05 / 27 / 98$ \\
\hline Bertelsmann Kirch / Premiere & Radio and television & $01 / 22 / 98$ & $05 / 27 / 98$ \\
\hline Airtours / First Choice & Air transport & $06 / 03 / 99$ & $09 / 22 / 99$ \\
\hline
\end{tabular}


Table 3

Year of notification and final decision for the 602 notifications in the final sample and home countries for the 1085 and 1070 firms in the sample on, respectively, the initial announcement and final decision dates.

\begin{tabular}{|c|c|c|c|c|c|c|c|c|c|}
\hline & & & & & & & & \multirow[b]{3}{*}{ Index } & \multirow[b]{3}{*}{ Currency $^{23}$} \\
\hline & Country & $\mathrm{N}$ & Country & $\mathrm{N}$ & & \\
\hline Year & $\mathrm{N}$ & Outcome & $\mathrm{N}$ & \multicolumn{2}{|c|}{ Announcement } & \multicolumn{2}{|l|}{ Decision } & & \\
\hline 1990 & 15 & Prohibition & 7 & Austria & 3 & Austria & 3 & $\begin{array}{l}\text { Weiner Boerse } \\
\text { Index }\end{array}$ & Schilling* \\
\hline 1991 & 47 & Conditions & 63 & Belgium & 19 & Belgium & 19 & $\begin{array}{c}\text { Brussels all } \\
\text { Shares }\end{array}$ & Franc* \\
\hline 1992 & 33 & Approval & 528 & Canada & 15 & Canada & 15 & Toronto 300 & Dollar \\
\hline 1993 & 40 & Referral $^{24}$ & 4 & Denmark & 8 & Denmark & 8 & Copenhagen SE & $\begin{array}{l}\text { Danish } \\
\text { Kröne }\end{array}$ \\
\hline 1994 & 55 & & & Finland & 14 & Finland & 14 & HEX & $\begin{array}{c}\text { Finish } \\
\text { Markka* }\end{array}$ \\
\hline 1995 & 69 & Total & 602 & France & 164 & France & 164 & CAC40 & Franc* \\
\hline 1996 & 57 & & & Germany & 176 & Germany & 176 & $\begin{array}{c}\text { DAX Kurs Price } \\
\text { Index }\end{array}$ & Mark* \\
\hline 1997 & 84 & & & Ireland & 1 & Ireland & 1 & Ireland SE & Punt* \\
\hline 1998 & 105 & & & Italy & 54 & Italy & 54 & Milan Comit & Lira* \\
\hline 1999 & 97 & & & Japan & 23 & Japan & 23 & NIKKEI 225 & Yen \\
\hline & & & & Luxembourg & 1 & Luxembourg & 1 & $\begin{array}{c}\text { Luxembourg SE } \\
13\end{array}$ & Franc* \\
\hline Total & 602 & & & Netherlands & 67 & Netherlands & 65 & $\begin{array}{l}\text { CBS All } \\
\text { Share }\end{array}$ & Guilder* \\
\hline & & & & Norway & 9 & Norway & 9 & Oslo SE General & $\begin{array}{c}\text { Norwegian } \\
\text { Kröne } \\
\end{array}$ \\
\hline & & & & South Africa & 10 & South Africa & 10 & JSE Industrial & Rand \\
\hline & & & & Spain & 16 & Spain & 16 & $\begin{array}{l}\text { Madrid SE } \\
\text { General }\end{array}$ & Peseta* \\
\hline & & & & Sweden & 42 & Sweden & 40 & $\begin{array}{c}\text { Affarsvarlden } \\
\text { weighted all } \\
\text { shares }\end{array}$ & $\begin{array}{l}\text { Swedish } \\
\text { Kröne }\end{array}$ \\
\hline & & & & Switzerland & 44 & Switzerland & 44 & $\begin{array}{l}\text { Swiss Market } \\
\text { Index }\end{array}$ & Franc \\
\hline & & & & UK & 180 & UK & 176 & FTSE 100 & Pound \\
\hline & & & & USA & 239 & USA & 232 & S\&P 500 & Dollar \\
\hline & & & & Total & 1085 & Total & 1070 & & \\
\hline
\end{tabular}

\footnotetext{
${ }^{23}$ Since January 1, 1999, euroland countries indicated by an asterisk have maintained fixed exchange rates with the euro (and hence with each other.)

${ }^{24}$ Referral to an individual EEC member state.
} 
Table 4

The simple market model: summary statistics

(1085 individual firm regressions)

\begin{tabular}{|c|c|c|c|c|}
\cline { 2 - 5 } \multicolumn{1}{c|}{} & $\alpha\left(\mathrm{X} 10^{3}\right)$ & $\beta$ & $\mathbf{R}^{2}$ & $\mathbf{F}$ \\
\hline Mean & -0.14 & 0.90 & 0.32 & 144. \\
\hline Std. Dev. & 1.00 & 0.30 & 0.20 & 184. \\
\hline Minimum & -9.00 & -0.39 & 0.00 & 0.00 \\
\hline 1st quartile & -0.68 & 0.71 & 0.16 & 37.9 \\
\hline Median & -0.03 & 0.91 & 0.29 & 81.6 \\
\hline 3rd quartile & 0.52 & 1.09 & 0.46 & 172. \\
\hline Maximum & 4.00 & 2.13 & 0.87 & 1387. \\
\hline
\end{tabular}

The R-square is unadjusted. The following tabulation gives percentages of individual regressions when various null hypotheses are rejected. For the JB test (Jarque-Bera) the null hypothesis is "normal disturbances"; for the ARCH test the null hypothesis is "homoscedasticity"; and for the Ljung-Box statistic of order 1, Q(1), the null hypothesis is "no autocorrelation".

\begin{tabular}{|c|c|c|c|c|c|}
\cline { 2 - 6 } \multicolumn{1}{c|}{} & \multicolumn{5}{c|}{ Hypothesis Rejected (\%) } \\
\hline p-level & $\boldsymbol{\alpha}=\mathbf{0}$ & $\boldsymbol{\beta}=\mathbf{0}$ & $\mathbf{J B}$ & $\mathbf{A R C H}$ & $\mathbf{Q ( 1 )}$ \\
\hline $\mathbf{1 \%}$ & 0.73 & 95.4 & 73.6 & 16.6 & 16.1 \\
\hline $\mathbf{5 \%}$ & 4.14 & 97.4 & 79.4 & 27.0 & 28.3 \\
\hline $10 \%$ & 8.20 & 97.9 & 82.8 & 34.0 & 35.0 \\
\hline
\end{tabular}


Table 5

\section{Price movement around the initial announcement of a business combination investigated by the European regulatory authorities.}

The dependent variable is an individual firm cumulative abnormal return (CAR) for the eleven-day event window centered on the initial announcement of a business combination. The market model was used to obtain the abnormal return. Explanatory variables are the firm's role (target, bidder, or joint venture), its home country (European or non-European,) size, type of EEC investigation, and eventual regulatory decision. MV is the natural logarithm of the firm's market capitalization at the end of the estimation period (approximately 35 days before the announcement.) All regressors except MV are dummy variables, which have the value 1.0 if the firm is in the indicated category and zero otherwise. TARGET is 1.0 if the firm is a target in a takeover. BIDDER is 1.0 if the firm is a bidder. If both TARGET and BIDDER are zero, the combination is a joint venture. NEEC is 1.0 if the firm is non-European. PhII is 1.0 if the firm is subjected to a Phase II investigation by the EEC. PROHIB is 1.0 if the combination is prohibited. COND is 1.0 if the combination is approved subject to conditions. REF is 1.0 if the proposed combination is referred to an individual EEC member state. If PROHIB, COND, and REF are all zero, the combination is approved outright.

\begin{tabular}{|r|c|c|c|}
\cline { 2 - 4 } \multicolumn{1}{c|}{} & Coefficient & t-statistic & p-value \\
\hline Intercept & 0.069 & 4.12 & 0.00 \\
\hline TARGET & 0.082 & 10.2 & 0.00 \\
\hline BIDDER & 0.012 & 1.65 & 0.09 \\
\hline NEEC & 0.026 & 3.92 & 0.00 \\
\hline MV & -0.0096 & -5.07 & 0.00 \\
\hline PhII & 0.010 & 0.65 & 0.51 \\
\hline PROHIB & -0.042 & -1.16 & 0.24 \\
\hline COND & 0.013 & 1.00 & 0.31 \\
\hline REF & 0.00882 & 0.24 & 0.80 \\
\hline
\end{tabular}

\begin{tabular}{|r|c|c|}
\hline Adjusted $\mathrm{R}^{2}$ & \multicolumn{2}{|c|}{0.15} \\
\hline $\mathrm{F}^{25}$ & 24.9 & 0.00 \\
\hline
\end{tabular}

${ }^{25} \mathrm{~F}$ test that all the coefficients (except the intercept) are zero. 
Table 6

\section{Probability of a Phase II investigation.}

The probability of a Phase II investigation of a proposed business combination is predicted by the domicile of the subject firm, the cumulative abnormal return (CAR) during the eleven-day initial announcement window, and the firm's market value (MV) on the last day of the estimation period (approximately 35 days prior to the initial announcement.) The dependent variable in a logit model is PhII, which is 1.0 if there is a Phase II investigation and zero otherwise. NEEC is 1.0 if the firm is non-European and zero otherwise. The model was estimated using individual firms as observations (as distinguished from proposed combinations.) Since only a small fraction of firms proceed to Phase II, the asymptotic t-statistic and p-value for the logit model might be unreliable. A bootstrap (resampling) procedure with 10,000 replications produced lower one-tailed p-values for all the coefficient point estimates.

\begin{tabular}{|r|c|c|c|c|}
\cline { 2 - 5 } & Coefficient & $\begin{array}{c}\text { asymptotic } \\
\text { t-statistic }\end{array}$ & $\begin{array}{c}\text { asymptotic } \\
\text { p-value }\end{array}$ & $\begin{array}{c}\text { bootstrap } \\
\text { p-value }\end{array}$ \\
\hline Intercept & -3.90 & -5.54 & 0.00 & \\
\hline NEEC & 0.09 & 0.35 & 0.72 & 0.350 \\
\hline CAR & 1.49 & 1.46 & 0.14 & 0.022 \\
\hline MV & 0.14 & 1.78 & 0.07 & 0.043 \\
\hline
\end{tabular}

\begin{tabular}{|c|c|c|}
\hline LR (zero slopes) ${ }^{26}$ & 5.10 & 0.164 \\
\hline$\%$ correct predictions & 0.93 & \\
\hline
\end{tabular}

\footnotetext{
${ }^{26}$ Likelihood ratio test that all slope coefficients in the logit model are zero.
} 
Table 7

\section{Probabilities of the European Commisssion's final regulatory decision.}

A multinomial logit model is estimated for three distinct final EEC regulatory decisions: (1) Authorization; (2) Authorization subject to conditions; and (3) Prohibition. The decisions can be rendered after either the Phase I or Phase II investigations. Prohibition is adopted as the base case, so a positive coefficient signifies a higher probability of each respective alternative to prohibition. Predictors are the cumulative abnormal return (CAR) during the eleven-day initial announcement window, the firm's market value (MV) on the last day of the estimation period (approximately 35 days prior to the initial announcement.), and the domicile of the subject firm. NEEC is 1.0 if the firm is nonEuropean and zero otherwise. The model was estimated using individual firms as observations (as distinguished from proposed combinations.)

\begin{tabular}{|r|c|c|c|}
\cline { 2 - 4 } \multicolumn{1}{c|}{} & Coefficient & t-statistic & p-value \\
\hline Authorization subject to conditions instead of Prohibition \\
\hline Intercept & -1.21 & -0.74 & 0.45 \\
\hline NEEC & -0.20 & -0.28 & 0.77 \\
\hline CAR & 7.14 & 1.72 & 0.08 \\
\hline MV & 0.40 & 2.10 & 0.03 \\
\hline Outright authorization instead of Prohibition \\
\hline Intercept & 4.01 & 2.66 & 0.00 \\
\hline NEEC & 0.04 & 0.05 & 0.95 \\
\hline CAR & 4.38 & 1.07 & 0.28 \\
\hline MV & 0.05 & 0.32 & 0.74 \\
\hline LR (zero slopes) & \\
\hline & 29.89 \\
\hline
\end{tabular}

${ }^{27}$ Likelihood ratio test that all slope coefficients in the multinomial logit model are zero. 
Figure 1. Stages of the European Commission's Control of Business Combinations.

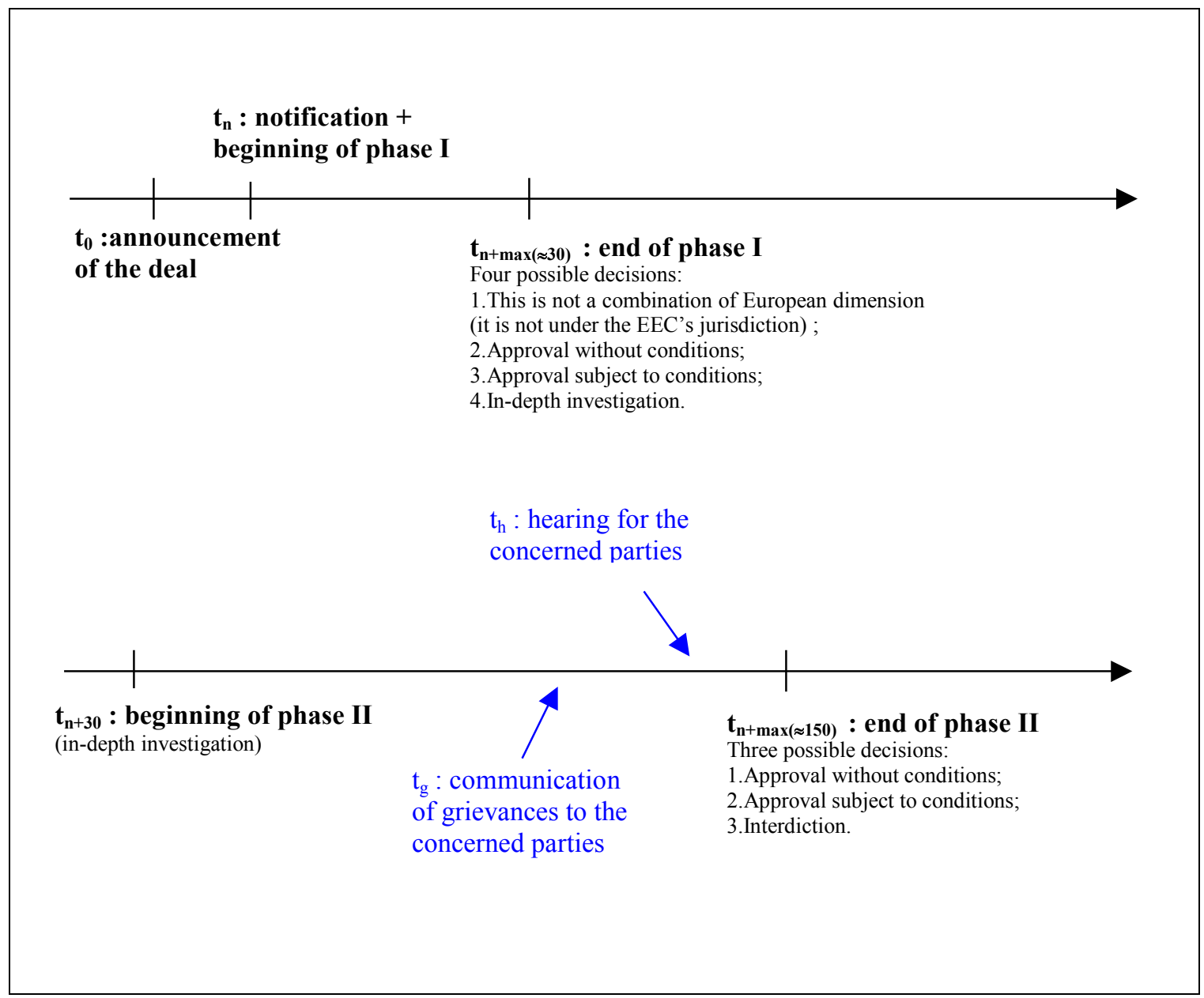


Figure 2. Industry Breakdown for Combinations Notified to the EEC, 1990-1999

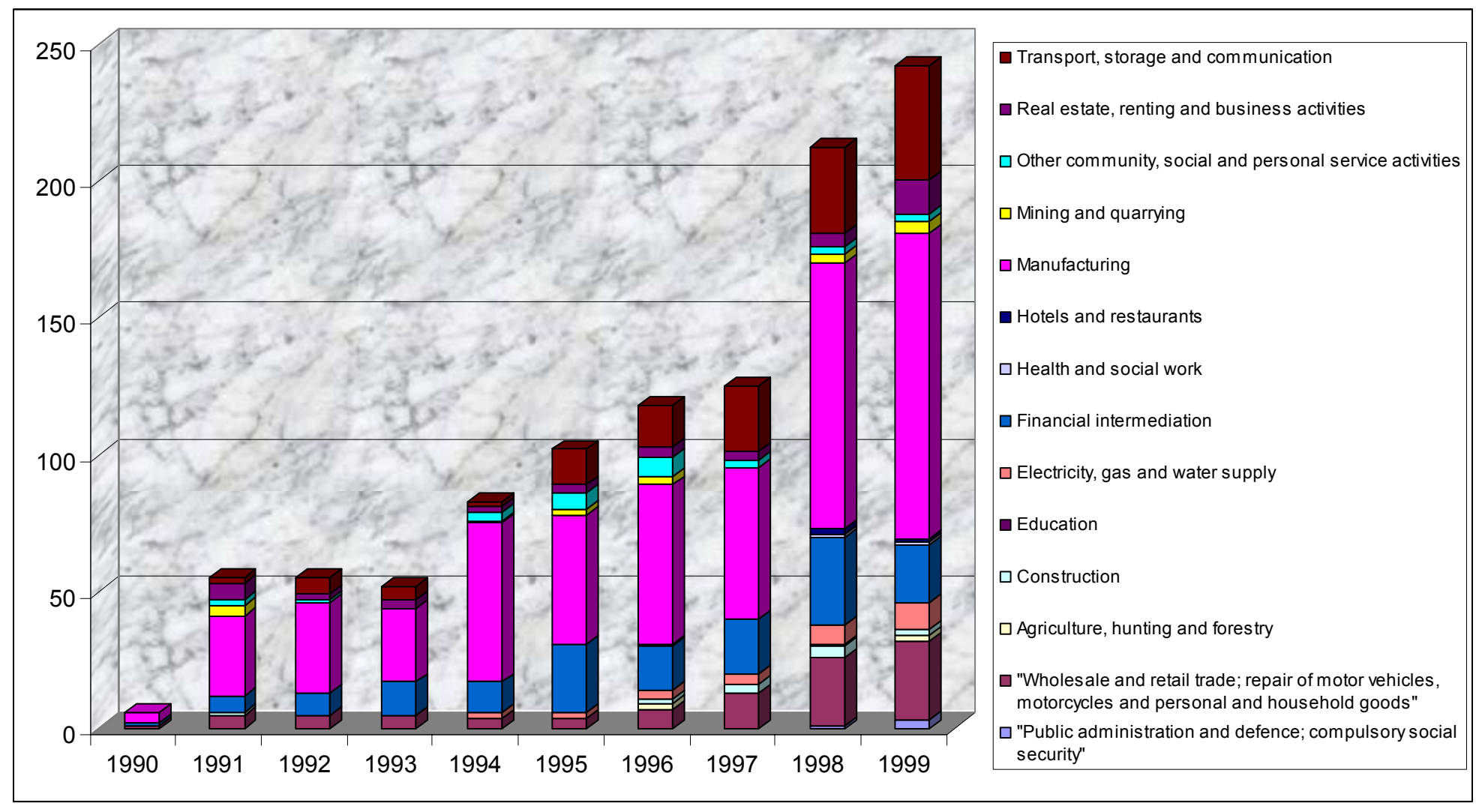


Figure 3. Price and Volume Charts for Selected Firms Involved in Phase II Proceedings with European Commission Regulators.
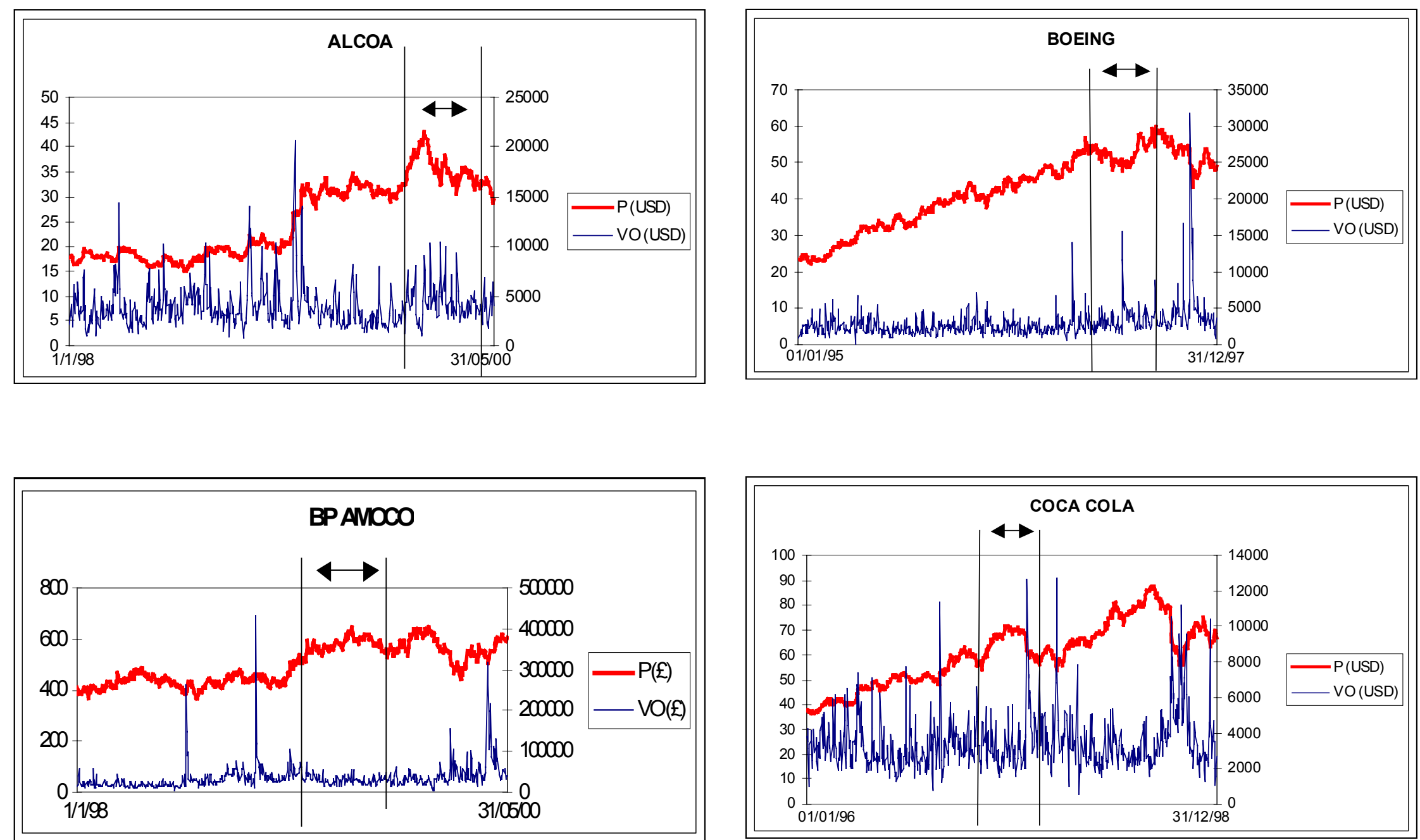

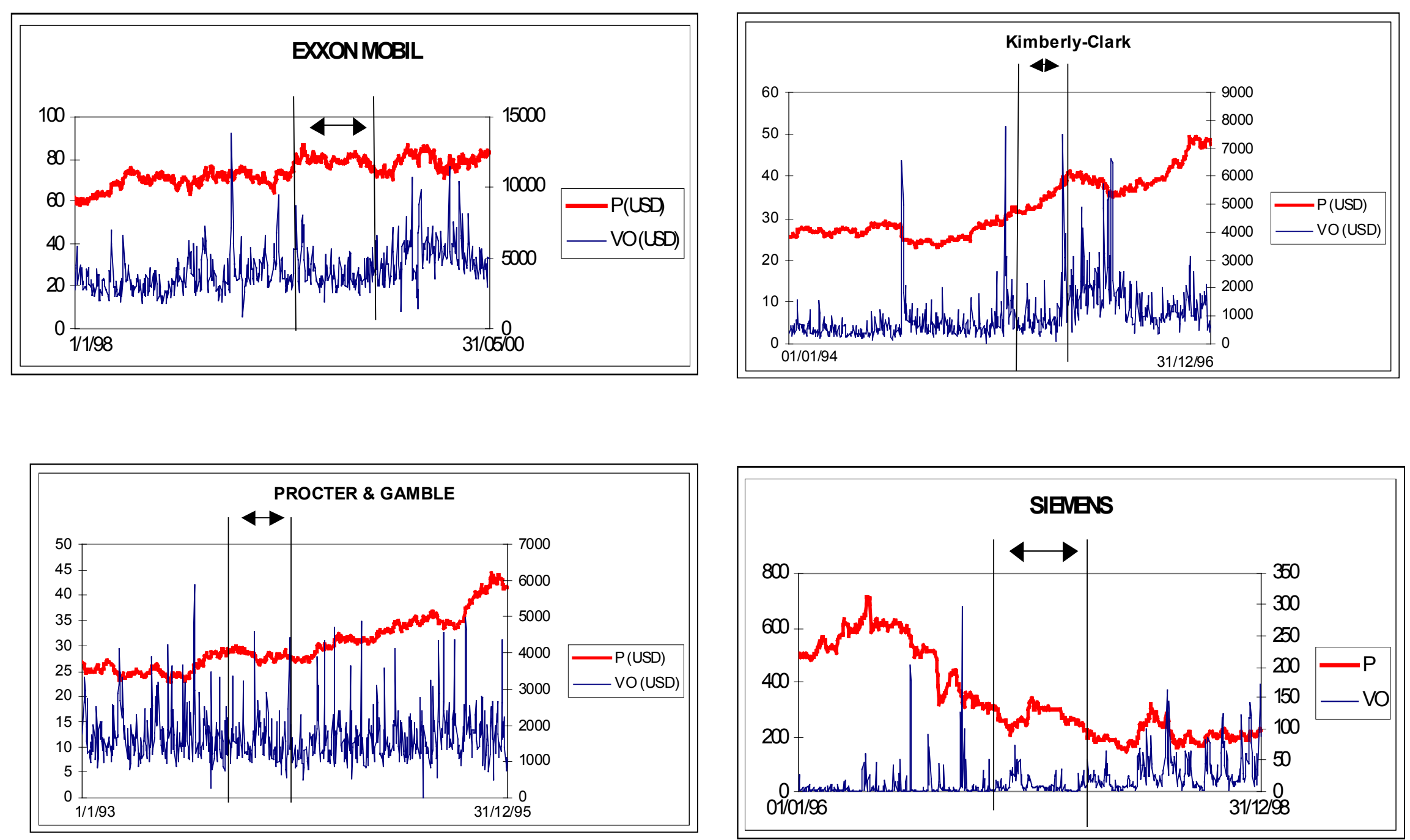
Figure 4

Panel A. Initial Announcement of Business Combination, All Firms, Market Model (MM), Scholes-Williams (SW), Constant Mean Return (CMR)

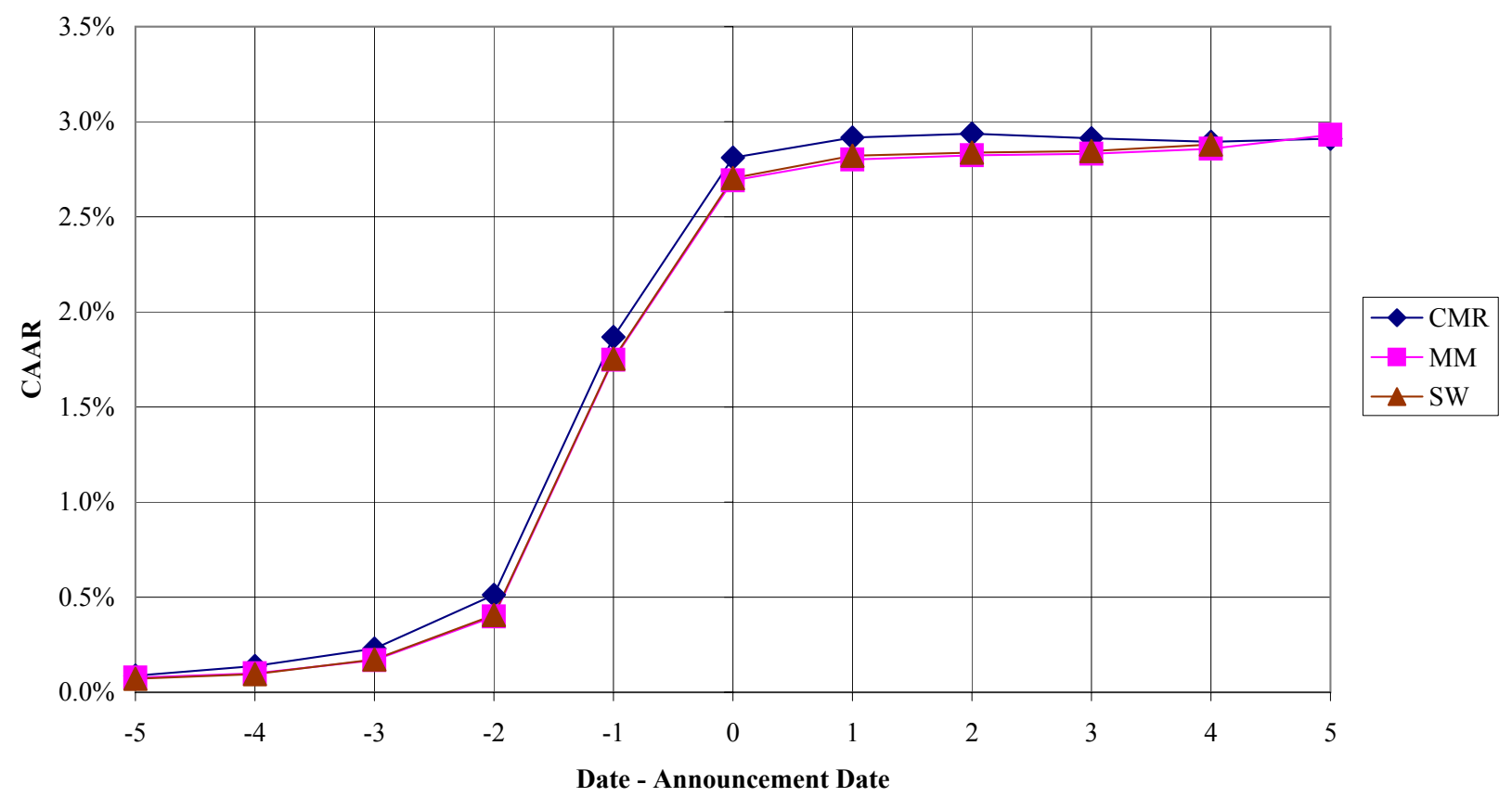

Panel B. Notification of Business Combination, All Firms, Market Model (MM), Scholes-Williams (SW), Constant Mean Return (CMR)

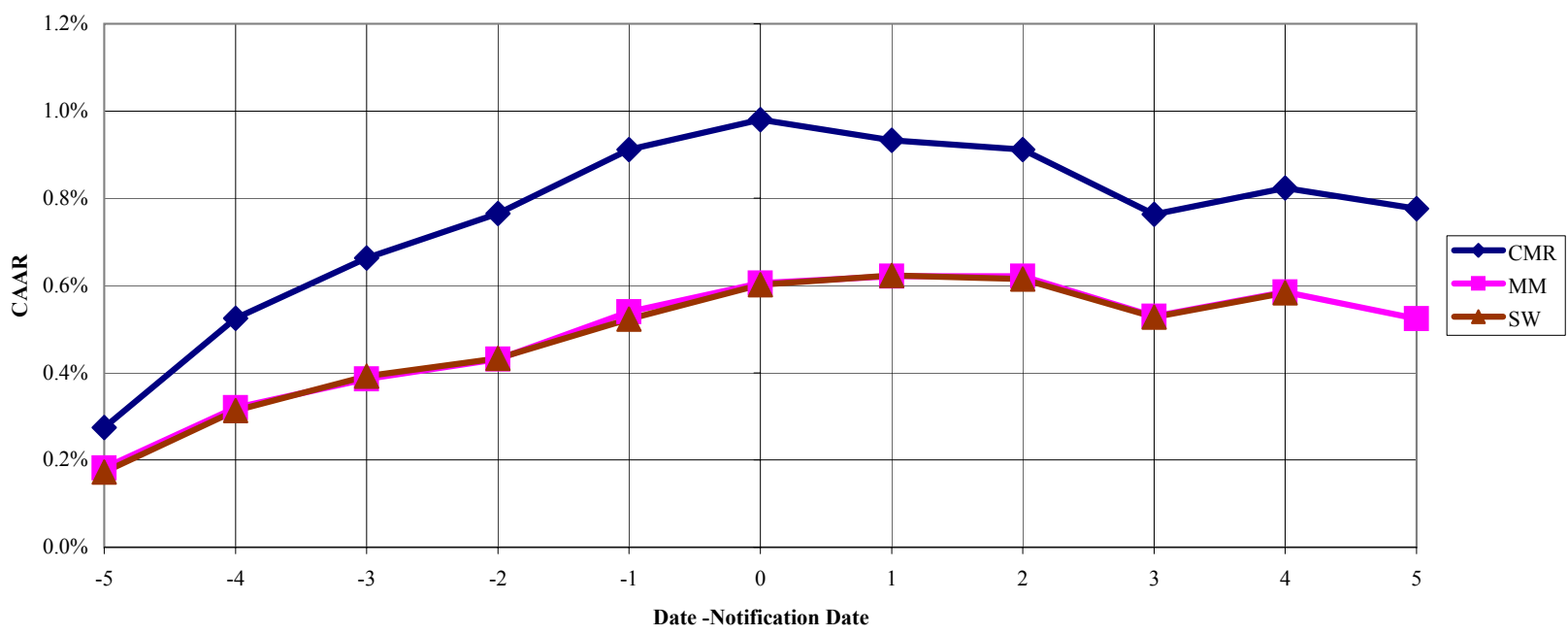


Panel A. Initial Announcement of Business Combination

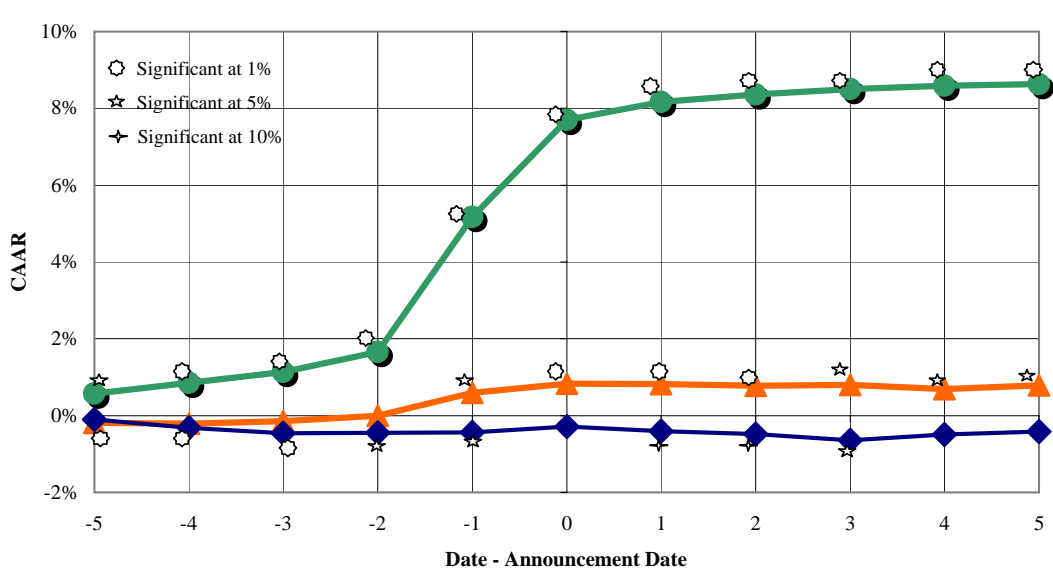

Panel B. Announcement of Phase II investigation

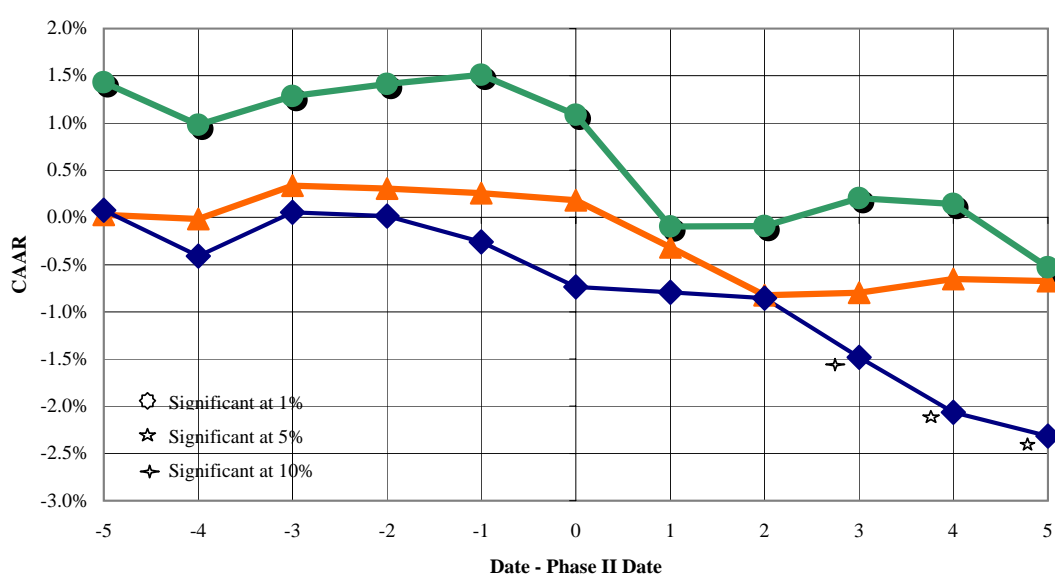

Figure 5

Panel C. Announcement of termination after Phase I

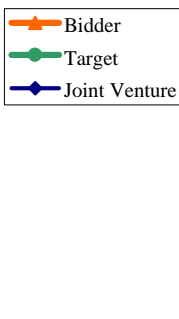

- - Bidder - $\rightarrow$ Target

$\rightarrow$ Joint Venture

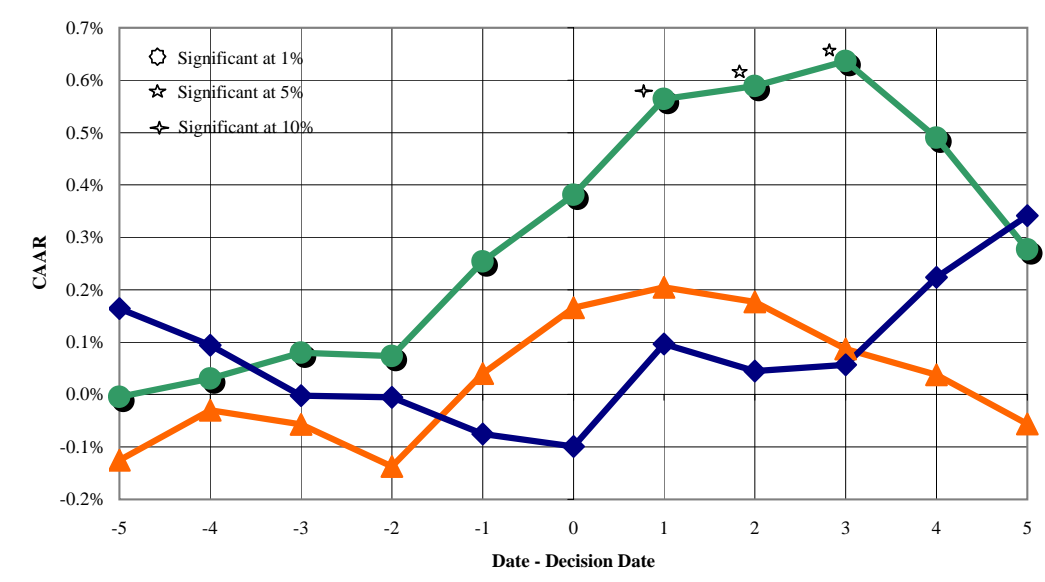

Panel D. Announcement of Decision after Phase II investigation

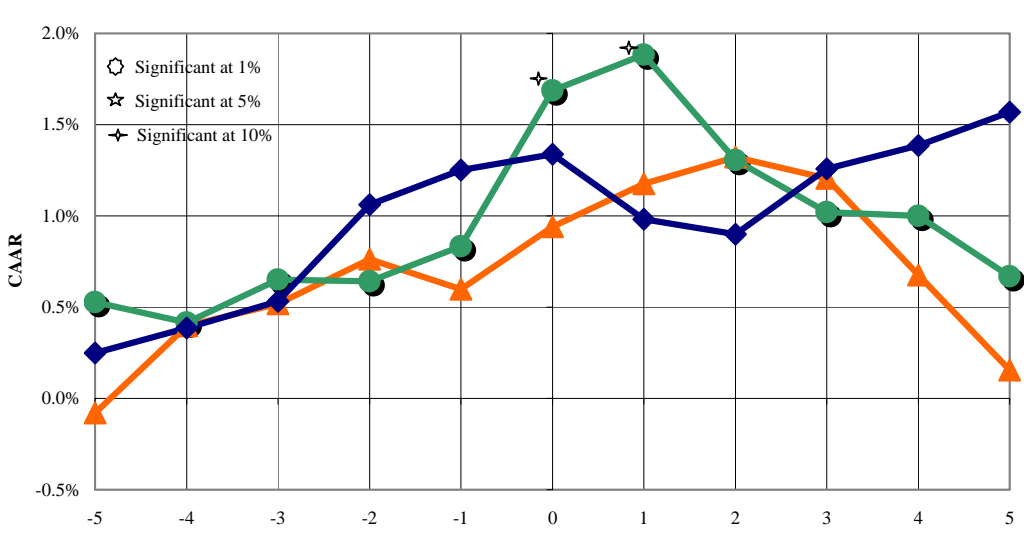

Date - Decision Date 
Figure 6

Panel A. Initial Announcement of Business Combination,

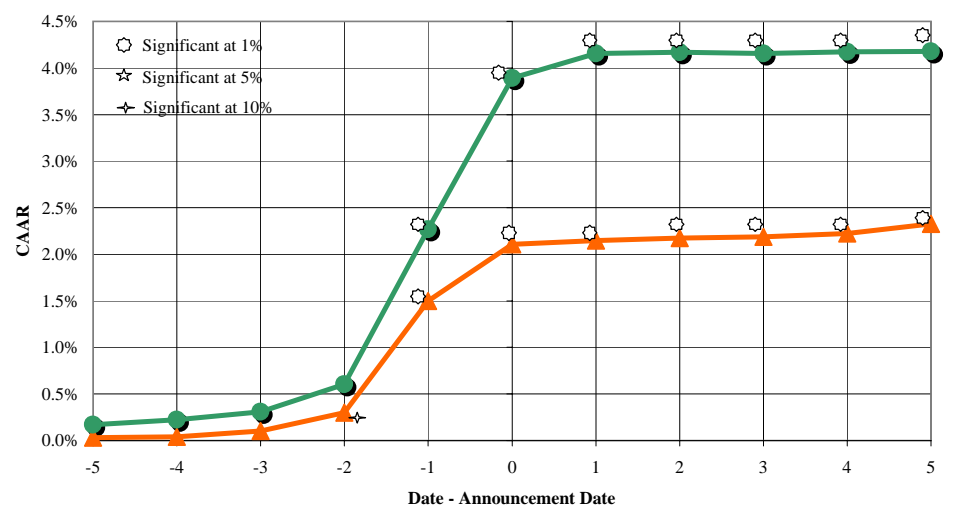

Panel B. Initial Announcement of Business Combination

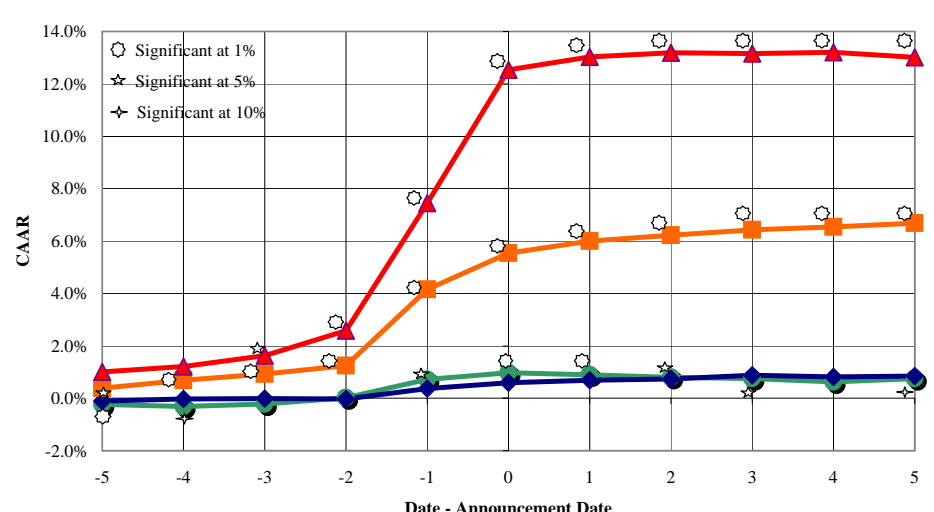

Panel C. Announcement of Phase II investigation

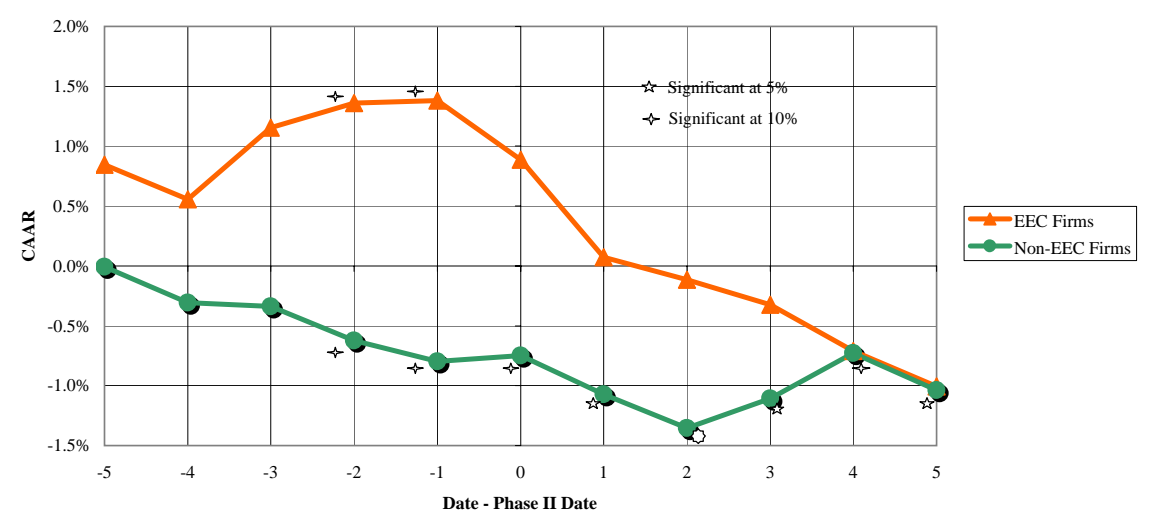

Panel D. Announcement Decisions Terminating Phases I or II

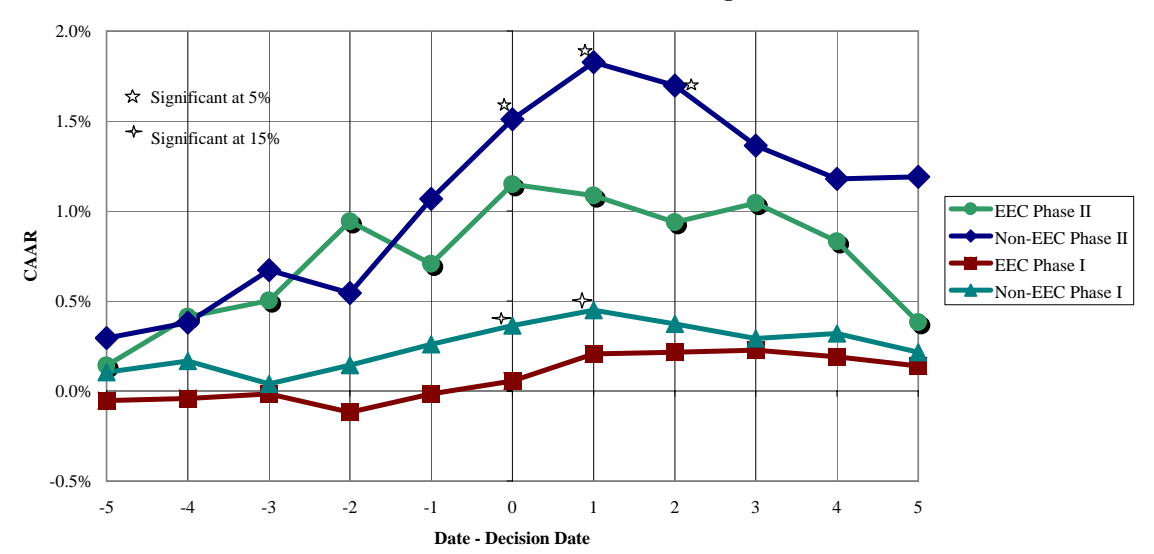


Figure 7

Panel A. Initial Announcement of Business Combination, for Firms Ending in Phase I and Phase II Proceedings

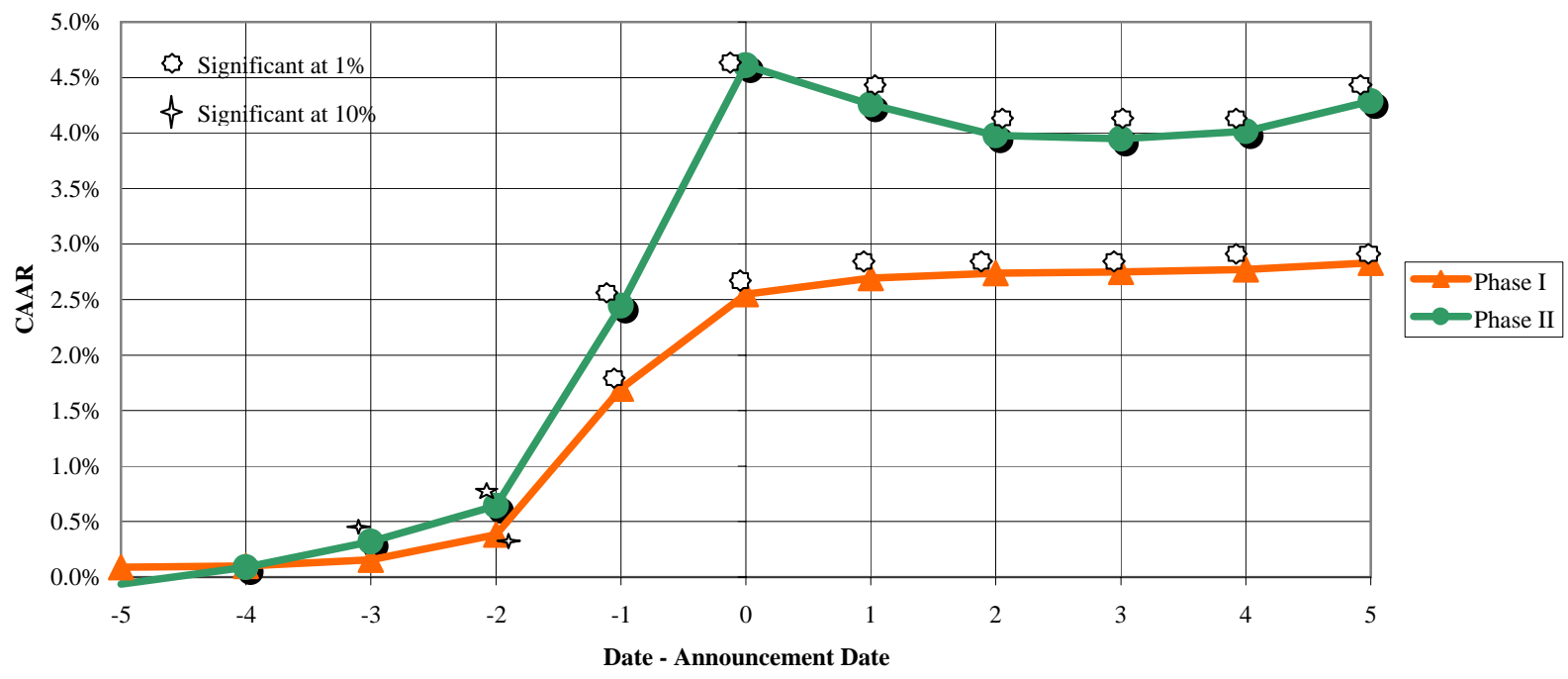

Panel B. Initial Announcement of Business Combination, by the Final Outcome (after either Phase I or Phase II)

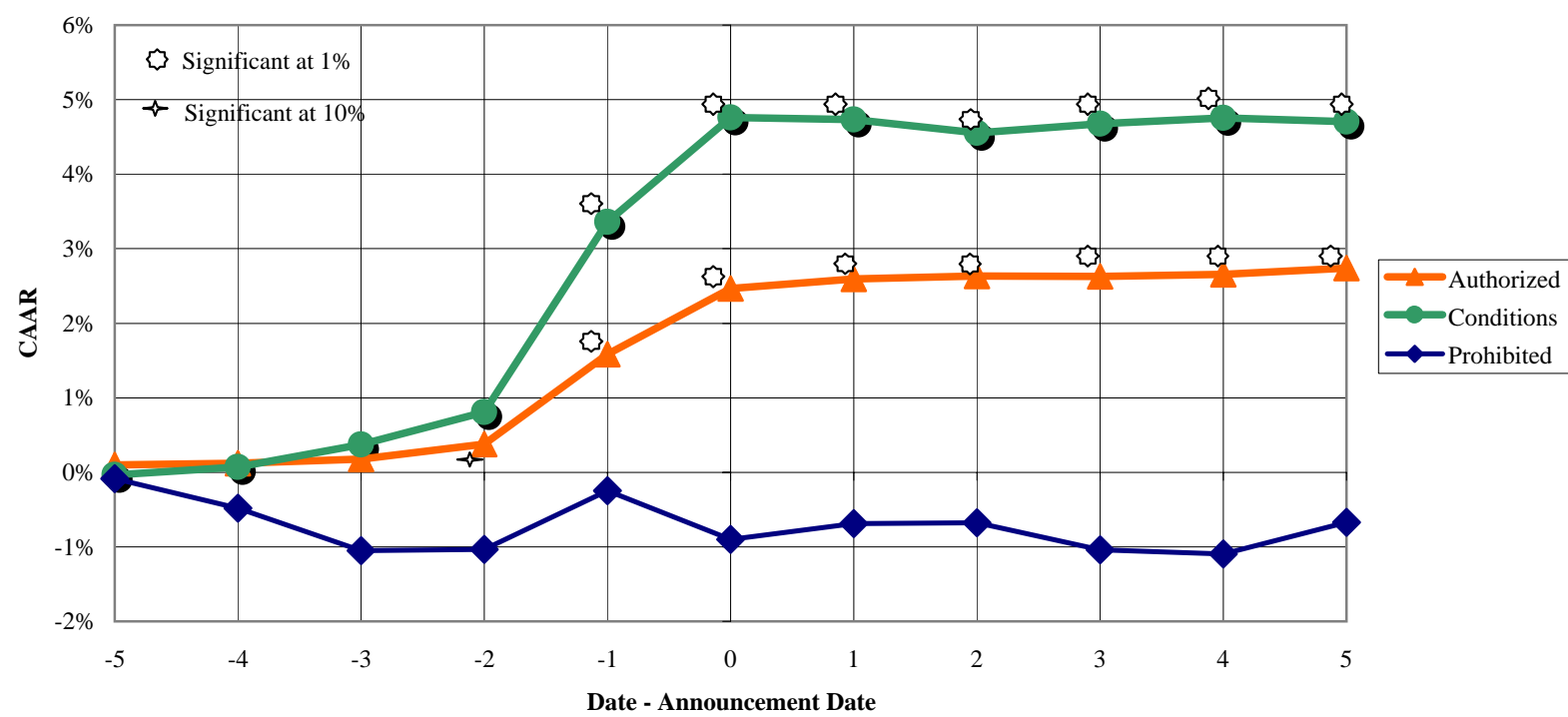


Figure 8

Panel A. Announcement of the Decision by Outcome After Either Phase I or II

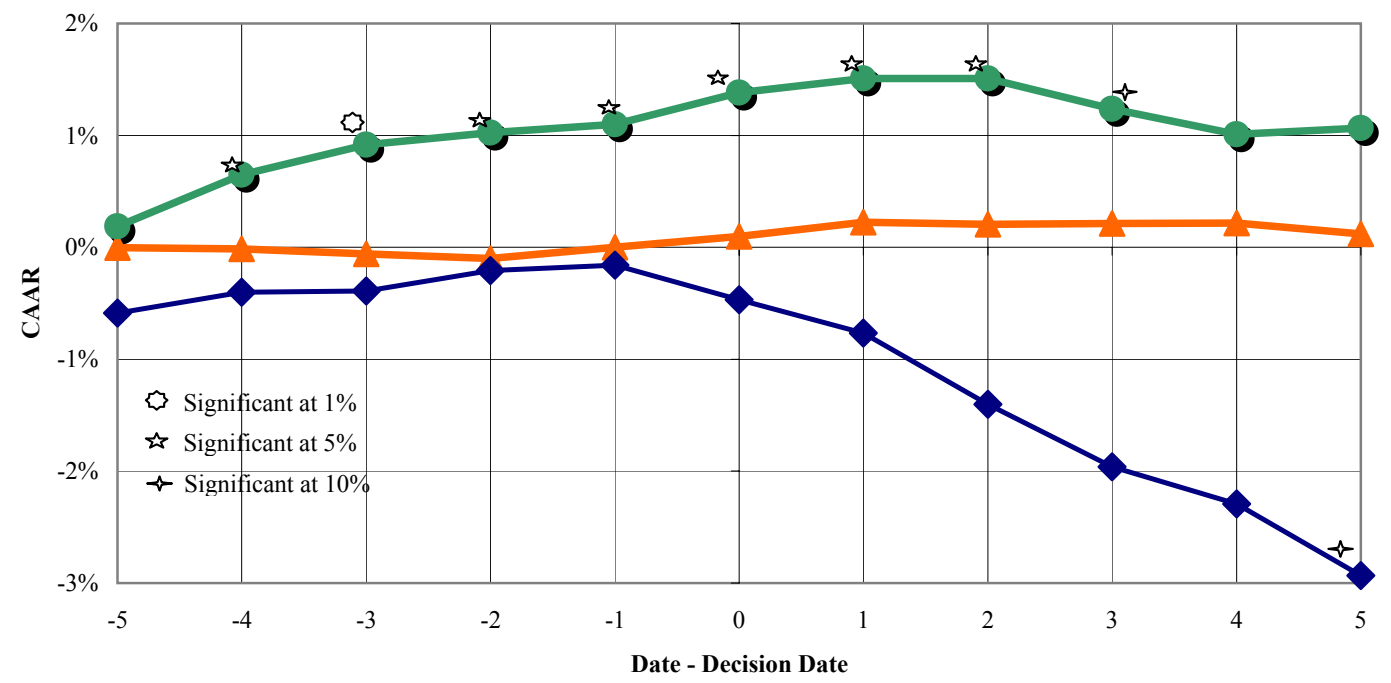

$\longrightarrow$ Authorization $\longrightarrow$ Conditions $\longrightarrow$ Prohibition

Panel B. Announcement of Phase II investigation by Ultimate Outcome

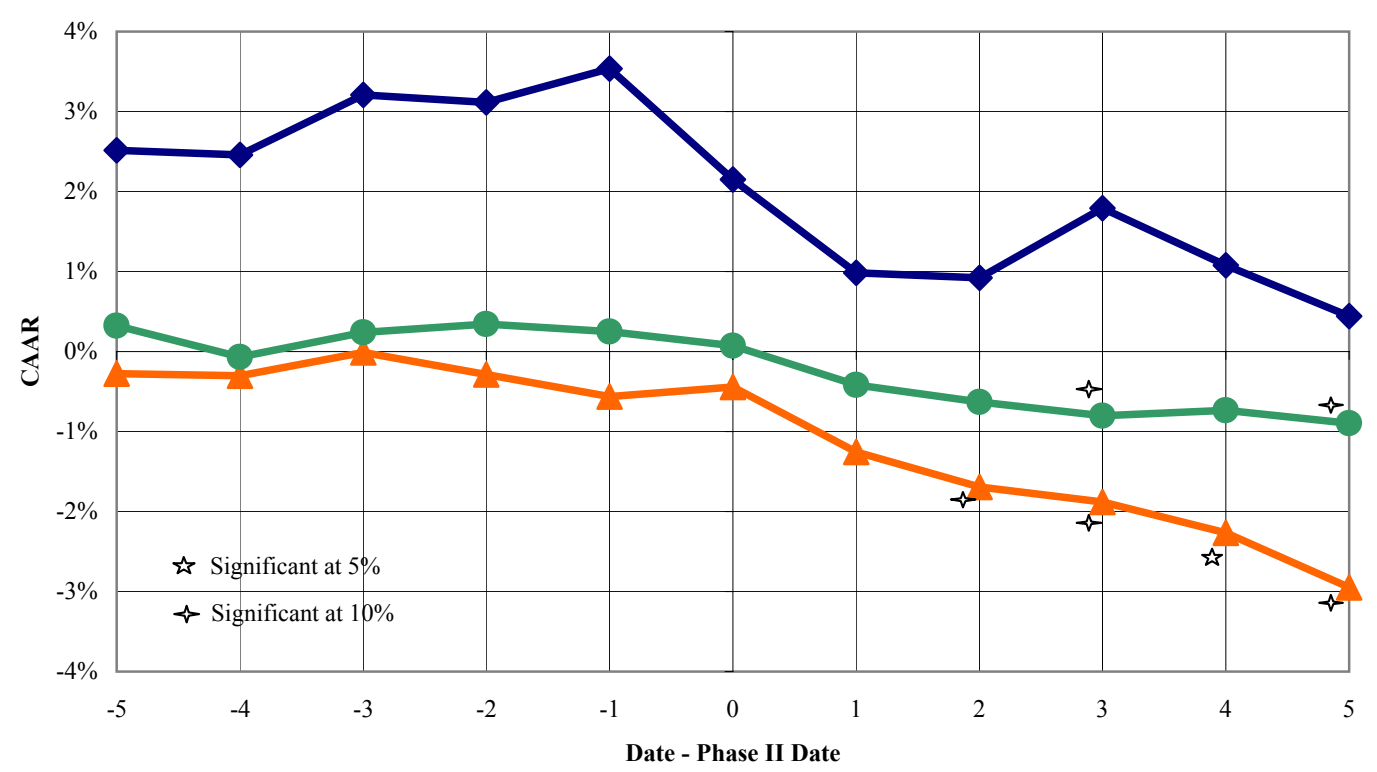


Figure 9. Initial Announcement of Business Combinations,

With and Without Holding Companies (HC) for EEC and non-EEC Firms

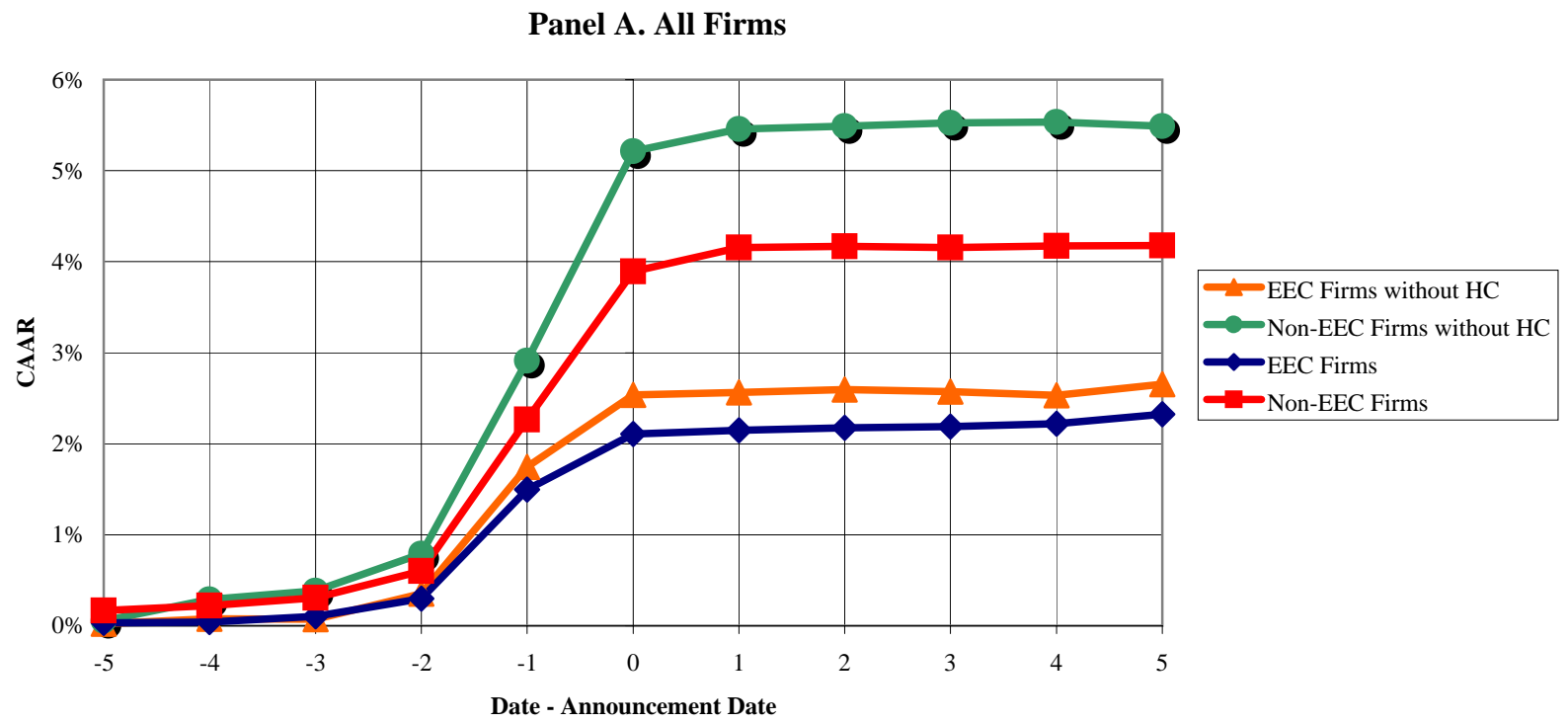

Panel B. Target Firms

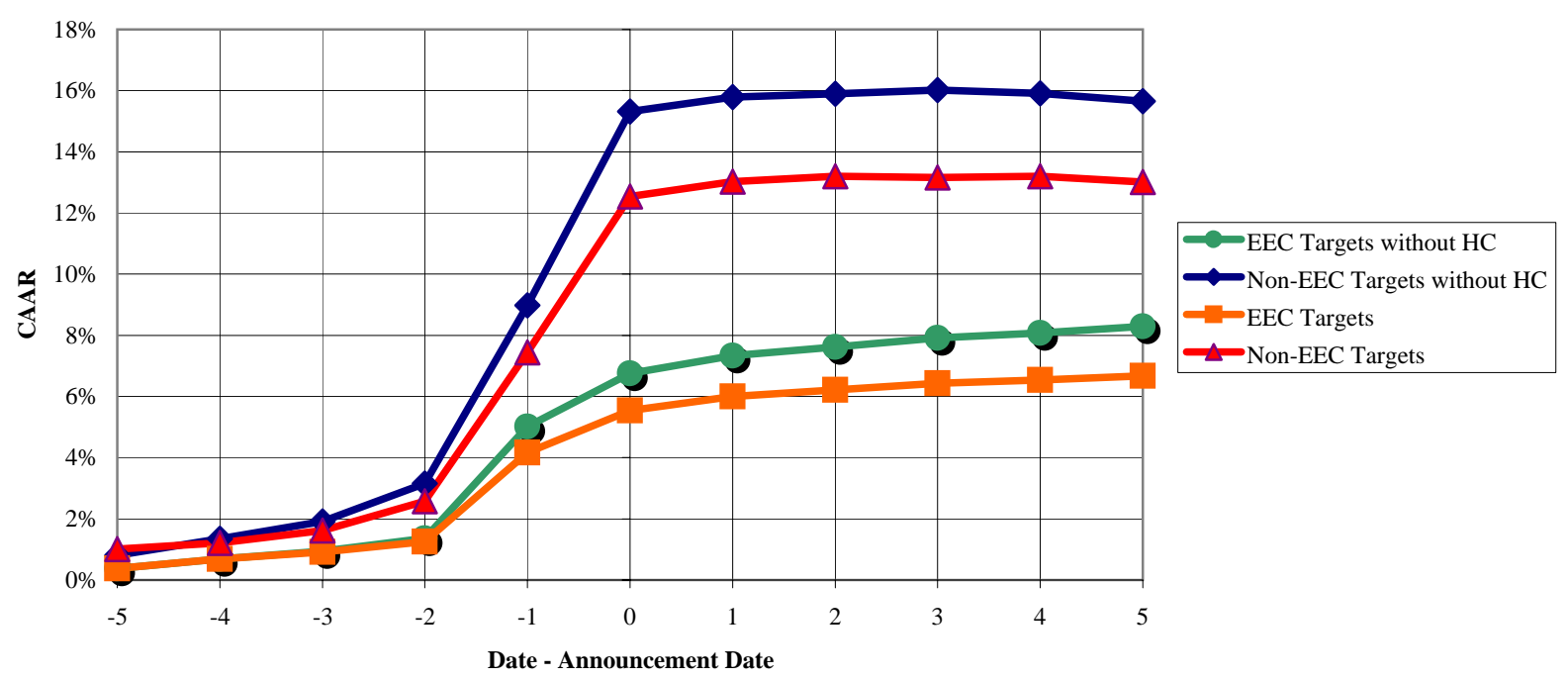


Figure 10

Panel A. R-Square Distribution of Market Model Estimation US\$ vs. Local Currency

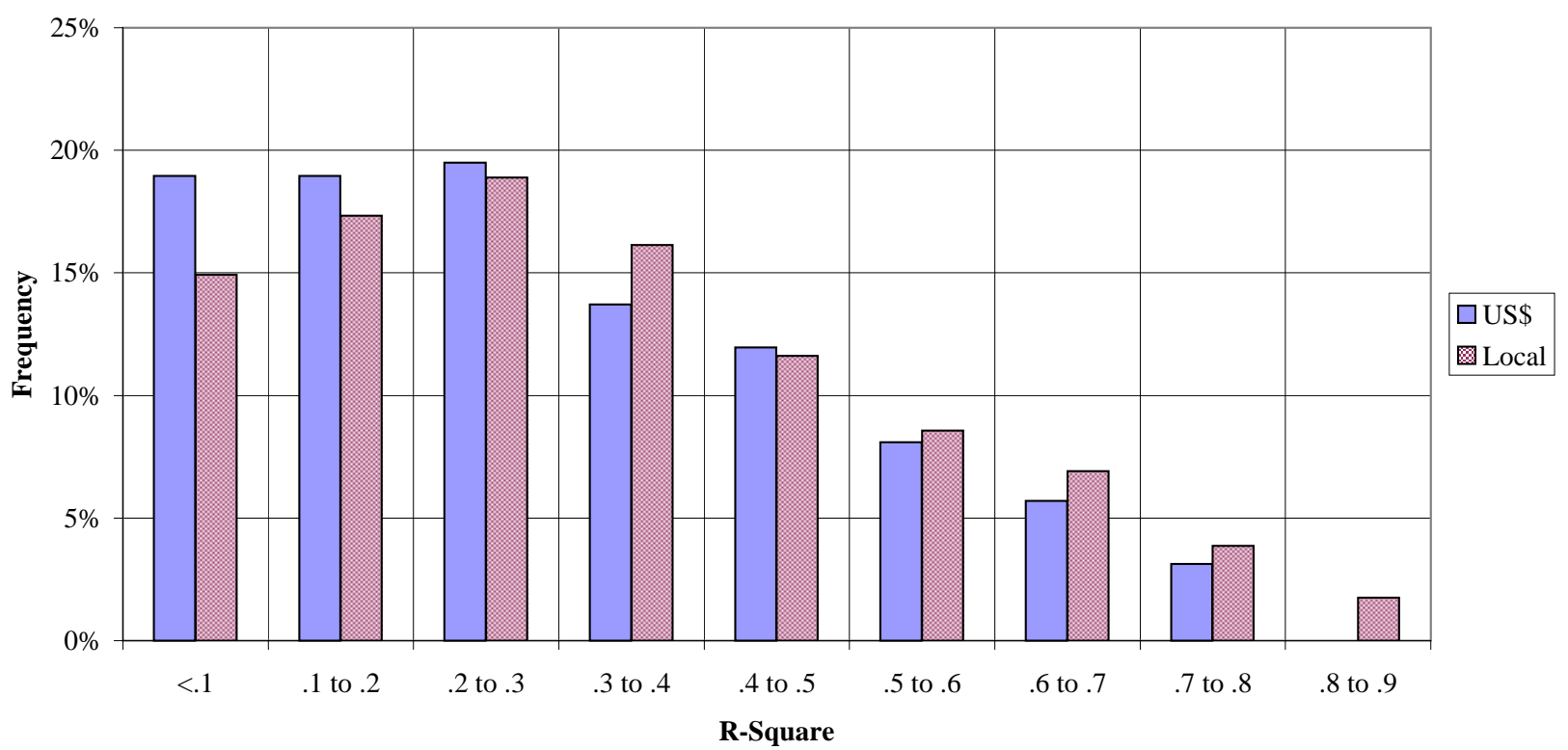

Panel B. Initial Announcement of Business Combination, Target, Bidder, and Joint Venture Deals, US\$ versus Local currency

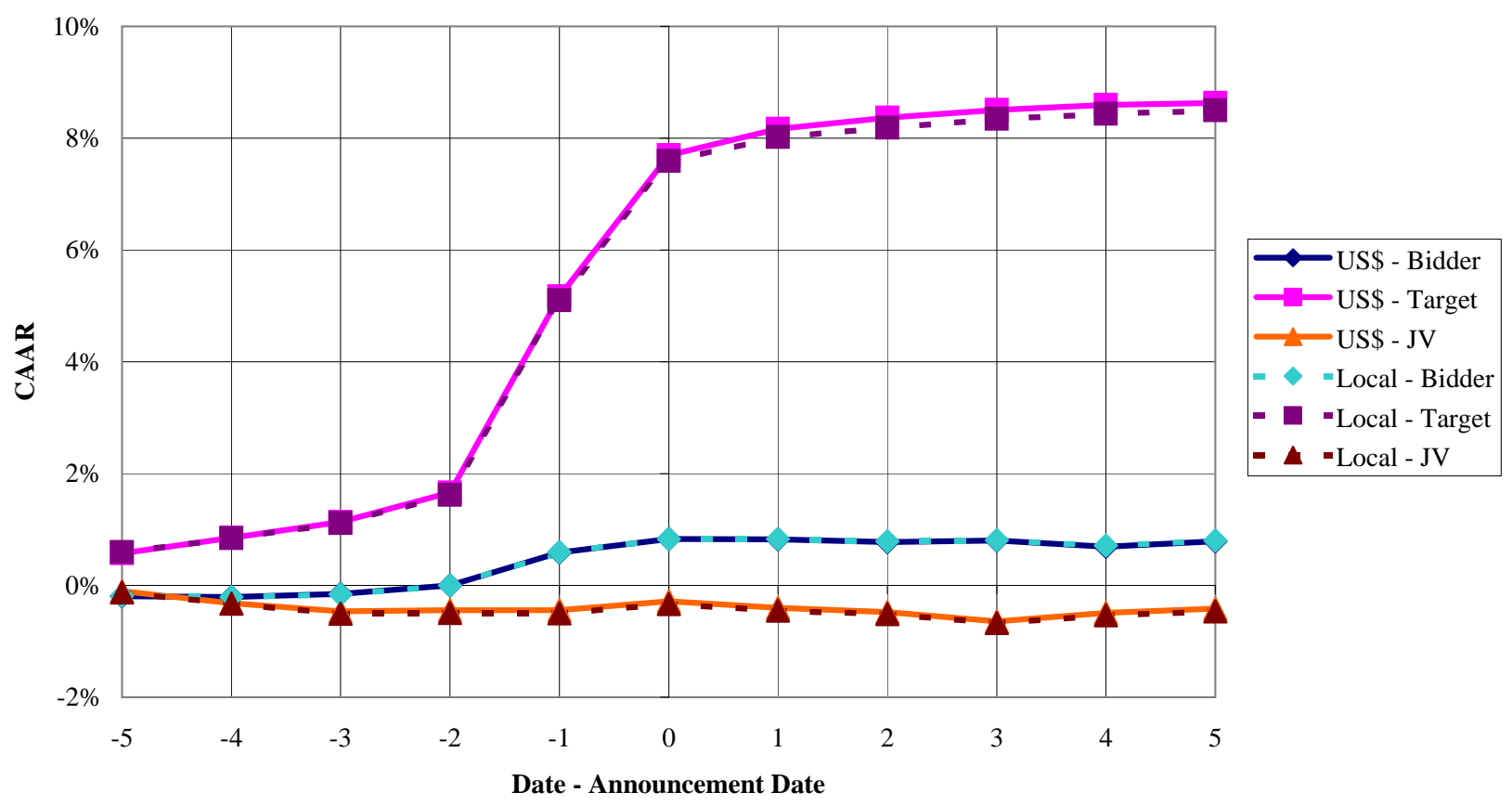


Figure 11. Initial Announcement of Business Combination, Target, Bidder, and Joint Venture Deals

All firms vs. Non-Suspended firms

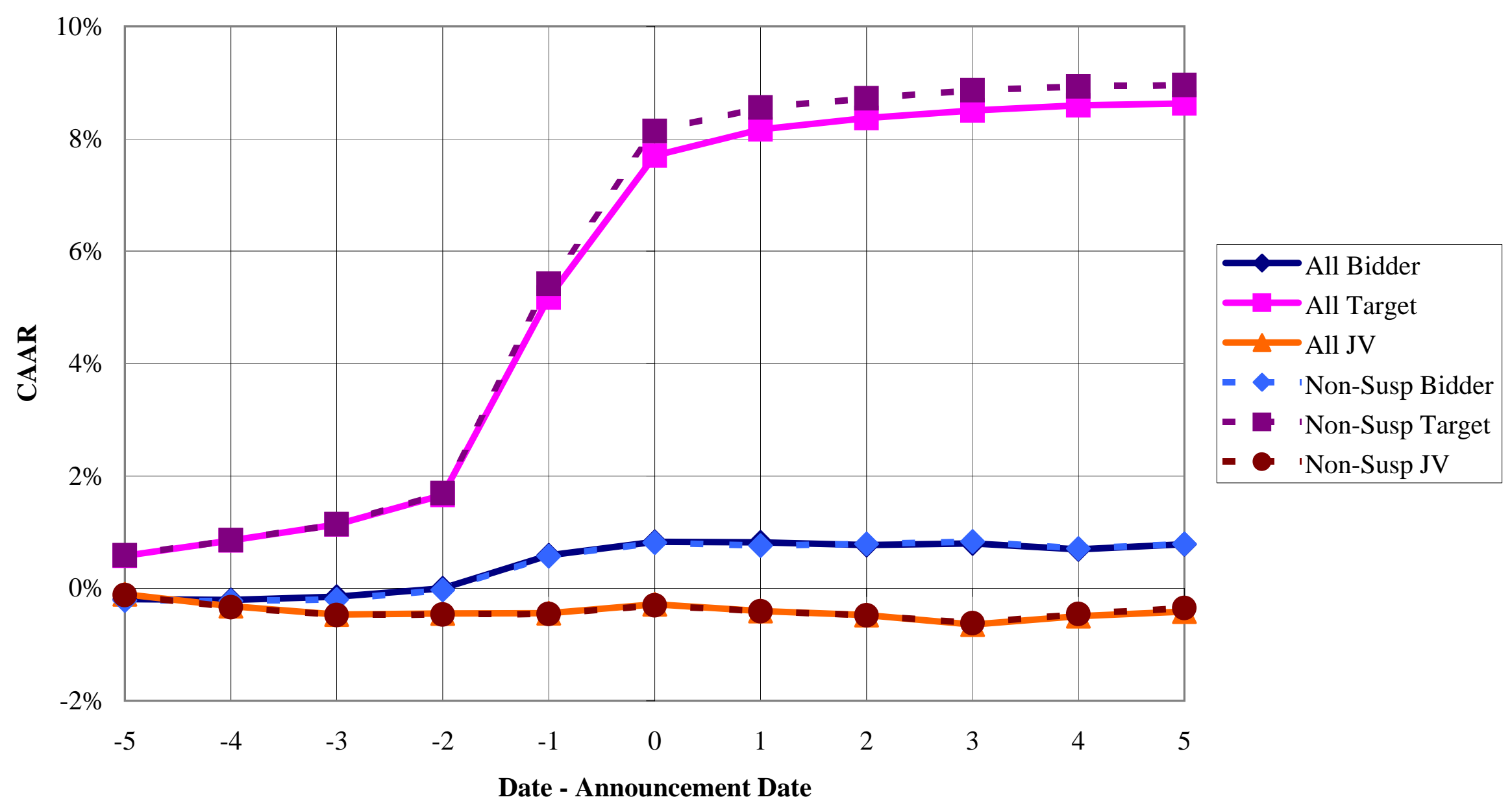

